University of Rhode Island

DigitalCommons@URI

Open Access Master's Theses

1993

\title{
The Relationship of Birth-Order and Sex of Infant to Mothers' Helping Behavior and Home Environment
}

Cynthia A. O'Connell

University of Rhode Island

Follow this and additional works at: https://digitalcommons.uri.edu/theses

\section{Recommended Citation}

O'Connell, Cynthia A., "The Relationship of Birth-Order and Sex of Infant to Mothers' Helping Behavior and Home Environment" (1993). Open Access Master's Theses. Paper 1697.

https://digitalcommons.uri.edu/theses/1697

This Thesis is brought to you for free and open access by DigitalCommons@URI. It has been accepted for inclusion in Open Access Master's Theses by an authorized administrator of DigitalCommons@URI. For more information, please contact digitalcommons@etal.uri.edu. 


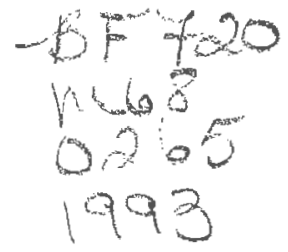

THE RELATIONSHIP OF BIRTH-ORDER AND SEX OF INFANT TO MOTHERS' HELPING BEHAVIOR AND HOME ENVIRONMENT BY CYNTHIA A. O'CONNELL

A THESIS SUBMITTED IN PARTIAL FULFILLMENT OF THE REQUIREMENTS FOR THE DEGREE OF MASTERS OF SCIENCE

IN HUMAN DEVELOPMENT AND FAMILY STUDIES

UNIVERSITY OF RHODE ISLAND

$$
3.995+65
$$




\section{ABSTRACT}

This study examines mothers' helping behavior in relation to birth-order and sex of one year old infants. The sample selected for this study was composed of sixty children and their mothers. A one hour home visit was conducted in order to video tape mother/child interaction during four problem solving tasks. The results suggest that regardless of birth order, there were no overall sex difference on any measure of mothers helping behavior, aspects the home environment, or demographic variables. However, the results suggest there to be an overall birth order difference with mothers of first born children using more negative statements during the problem solving tasks. Further analysis controlling for sex found that birth-order makes a difference for boys only. Mothers of first born boys expressed significantly more negative statements and unrelated statements. A secondary objective of this study was to examine differences in the home environment in relation to birthorder and/or sex of the child using the Home Observation for Measurement of the Environment (HOME). The results suggest that regardless of the sex of the infant, mothers of second born children scored significantly higher than mothers of first born children on HOME inventory sub-scale II (Avoidance of restriction and punishment). Interestingly, mothers who scored significantly higher on sub-scale II (Avoidance of restriction and punishment) also used less negative statements during the problem-solving tasks. Mothers who scored higher on sub-scale $V$ (Maternal emotional and verbal involvement with child) also gave more verbal instruction during the problems solving tasks. 
Acknowledgment

I would like to thank Dr. David Caruso for the input and feedback he has provided me. I have learned a great deal about the field of research through my experience as Dr. Caruso's graduate research assistant. This experience has provided me with an abundance of ideas for my own thesis research project.

Dr. Gwenneth Rae has been a tremendous source of inspiration, not only in terms of providing me with ideas for my thesis research, but in other areas of my education as well. I have found her to be a very knowledgeable professor who takes a genuine interest in making sure students reach their potential. When I was fortunate enough to have Dr. Rae as a professor, I found myself being motivated to constantly challenge myself both as a student, as well as an individual. I cannot thank her enough for her constant support, knowledge, and insight. I would also like to thank her being a member of my thesis committee.

Although I have not had the opportunity to have Dr. Janet Kulberg or Dr. Susan Bradey as professors, they have been helpful by providing me with ideas for improving my thesis. I would like to thank $\mathrm{Dr}$ Janet Kulberg for serving as a member on my thesis committee and Dr. Susan Bradey for chairing my thesis defense.

I would like to take the opportunity to thank my family for the never ending support and encouragement they have provided me throughout my education. I appreciate all they have done in making it possible for me to reach my potential. THANK YOU... 


\section{Table of Contents}

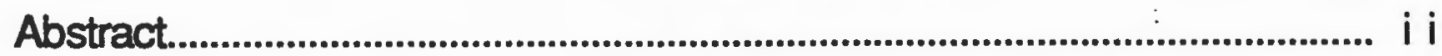

Acknowledgement.......................................................................................... i i i

Table of Contents........................................................................................ iv

List of Tables................................................................................................. vi

Introduction.................................................................................................... 1

1. Statement of the Problem.......................................................... 2

2. Predictions........................................................................................... 7

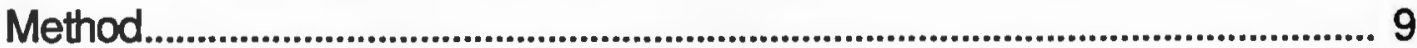

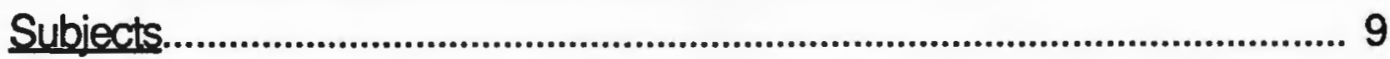

Procedures................................................................................................... 9

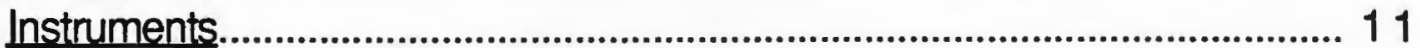

1. HOME Interview.......................................................................... 12

2. Problem-Solving tasks............................................................. 14

Measures.................................................................................................... 15

1. HOME Interview..................................................................... 15

2. Problem-Solving tasks.............................................................. 16

3. Demographic variables.................................................................. 16

Results........................................................................................................................... 17

Specific Predictions................................................................................ 20

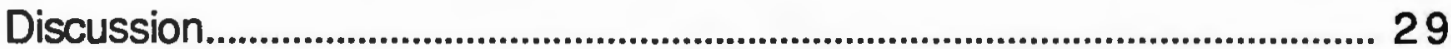

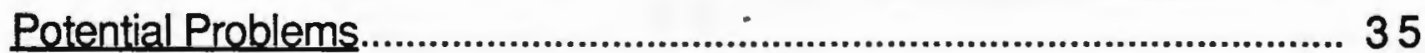

Conclusions................................................................................................ 36

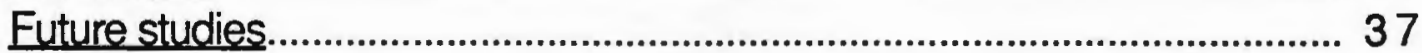

References.......................................................................................................... 38

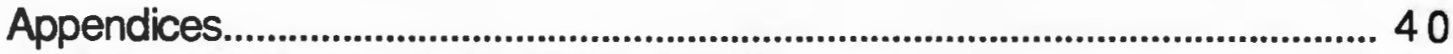

Appendix A, Extensive Literature Review.................................... 40

Appendix B, Letter to Parents.......................................................... 54

Appendix C, Coding Sheet................................................................ 55

Appendix D, Consent Form for Research........................................ 56

Appendix E, HOME interview........................................................... 59

Appendix F, HOME inventory Code Sheet.......................................... 67

Appendix G, Instructions to Mother................................................... 73

Table of Contents 
Appendix $\mathrm{H}$, Instructions of the Tasks to the Mother ............... 74 Appendix I, Definitions of Mothers' Helping Behavior................ 75 Appendix J, Mother's Backgroung Data Questionaire.................. 76 
List of Tables

Table Page

1. Means and Standard Deviations for Mothers' Helping Behavior and HOME Scores by Sex and Birth-Order.

2. Means and Standard Deviations for Demographic Background Data by Sex and Birth-Order.

3. Anova analysis of the Relationship of Infant Birth-Order to Mother's Helping Behavior.

4. Anova analysis of Birth Order on Mothers' Helping Behavior for Girls.

5. Anova analysis of the Relationship of Birth-Order effects for Boys to Mothers' Helping Behavior.

6. Correlations between Structural Variables and Mothers' Helping Behavior

7. Correlational analysis between Mothers' Helping Behavior and the HOME.

8. Correlational analysis between Demographic variables and Birth-Order.

9. Correlational analysis between Mothers' helping behavior and Demographic variables.

10. Correlational analysis between the HOME and Demographic variables.

11. Correlational analysis between aspects of mothers' helping behavior. 


\section{INTRODUCTION}

This study examined mothers' helping behavior in relation to sex and birth-order of one-year-old infants. In addition, differences in aspects of the home environment in relation to sex and birth order were examined using the Home Observation for Measurement of the Environment (HOME) (Bradley \& Caldwell, 1978).

One hypothesis of this study was that there are differences in mothers' helping behavior toward first-born infants as compared to second born male and female infants. A second hypothesis of this study was that there would be a significant increase in mothers' helping behavior toward female children as compared to male children.

It was also expected that scores on various HOME sub-scales would differ in relation to the sex and birth order of the infant. It was expected that mothers with male infants would score higher on HOME sub-scale II (Avoidance of restriction and punishment). Mothers have been found to be less involved and less intrusive in the lives of their sons in comparison to their daughters (Olver, Aries, \& Batgos, 1983). Mothers of female infants were expected to score higher on sub-scales I (Emotional and verbal responsivity of mother) and $V$ (Maternal involvement with child). The same research conducted by Olver, et al (1983), found maternal involvement in relation to birth order to be quite significant. Also, it was found that mothers tended to be more responsive, and involved in the lives of first born children, when compared with second-born children.

These findings were tested in the present study. In relation to the Home interview sub-scales, it was expected that in general, 
second born infants would score higher on sub-scale II when compared to first born infants. It was also expected that first born infants would score higher on sub-scales I (Emotional and verbal responsivity of mother) and $V$ (Maternal involvement with child) when compared to second born infants.

\section{Statement of the problem}

Birth-order and sex differences have been areas of interest for researchers in the field of human development for decades. Many studies have been conducted regarding the relationship of infant birth-order and sex to mother/child interaction. However, relatively few studies have examined the relationship of infant birth order and sex to different aspects of the home environment. This study not only examines birth order and sex differences, but it also examines the relationship between infant birth order and sex to maternal behavior and aspects of the home environment.

Much of the literature on sex differences suggest that males and females are raised with very different expectations placed upon them. The results of a study conducted by Bardwick and Douvan (1971) suggest that in general, boys are raised with the stereotyped expectations to be independent, aggressive, competitive and to be a leader. On the other hand, many girls are raised with opposite stereotyped expectations which are to be dependent, passive, nonaggressive, and to be interpersonally oriented. Males and females who exhibit these sex stereotyped behavior in later life are thought to have learned it early in life through parent/child interactions in infancy. 
Much of the research examining the relationship of sex of the child to mother/child interaction during problem solving and play have been mixed. Some of the studies cited in this review suggest there are no sex differences while others suggest that differences do exist. The literature suggesting there are sex differences does not appear to be able to reach a consensus regarding the differential ways mothers interact with their sons and daughters. An explination for these inconsistancies in the literature may be that some studies are more careful than others in controlling for variables, such as, socio-economic status, mother's age, age of children, spacing of children, mother's experiencing in work, education, and childcare settings.

The results of a study conducted by Olver, Aries and Botgos (1989), suggested that mothers tended to be more involved and intrusive in the lives of their daughters when compared to mothers of sons. This same study also suggested that mothers of son's tended to foster more independence when compared to mothers of daughters. Studies cited in Block (1983) conducted by Gunnar-Von and Gnechten, (1978) and Rothbart, (1971) suggest that compared to mothers of sons, mothers of daughters tended to offer more help to their children during problem solving situations even when help was not needed.

Similar research was conducted by Milton, Kagan, and Levine (1971) and Fristad and Karpowitz (1988). The results of these studies suggested the opposite to be true. Mothers of sons were found to be more involved and intrusive during problem solving situations and structured play situations than when compared with 
mothers of daughters. Milton et. al. (1971) suggested that mothers of sons also tended to reprimand and/or remove their child from a situation than mothers of daughters.

Although some birth order differences exist in the literature, the majority of the literature appears to agree that mothers of first born children tend to be more strict, highly involved and more directive in the lives of their first born children. Olver, et al (1989) suggest that these behaviors exhibited by mothers of first borns may contribute to difficulty in later life developing a separate sense of self.

A study conducted by Rule (1991), involved surveying college students with a questionaire to examine their perception of parental strictness-permissiveness. The results suggested that early memories of first born children perceive their parents as being much more strict and controlling in their lives as compared with their later born sibs. The results of the perception of second born college students further confirm this finding.

Both early studies by Stout (1960) and Lasko (1954) and more recent studies conducted by Rule (1991) Dunn, Stocker, and Plomin (1990) and Rothbart (1971) agree that mothers of firstborn children tend to intervene and offer help even when help is not needed. The early studies referred to above conducted by Stout (1960) and Lasko (1954) also suggest that parents tended to be more directive with their first born children. Lasko reported that when compared to parents of first born children, parents of second born children tended to intervene less often in problem solving situations and structured play. The results of the Dunn, et. al (1990) study suggest 
that not only did mothers of second born children intervene less often in problem solving and structured play settings, and were less restrictive in terms of regulating their play. The Dunn et. al study also suggests that there is far more parental pressure placed upon first born children to succeed than when compared to the pressure placed upon second born children to succeed.

An early study conducted by Hilton (1967) relates well to the findings of Dunn (1990) concerning parental pressure placed on first born children to succeed. The results of Hilton's study suggests that when compared with mothers of second born children, mothers of first born children use significantly more positive statements as a reward and a demonstration of love when the child was successful on a task. In this same study it was found that mothers of first born children also withheld positive demonstrations of love when the child failed on a task. The results for mothers of second born children suggested that regardless of the child's success or failure the mothers tended to be much more consistent with their demonstration of love and positive statements to the child.

Although there appears to be an abundance of literature concerning the relationship of infant birth-order and sex to mother/child interaction, few studies have examined the relationship of infant birth order, and sex to the home environment.

Betty Caldwell developed a tool to help researchers find out more about the home environment of children. The name of this tool is the Home Observation for Measurement of the Environment (HOME). The HOME is in the form of an interview. The HOME was used in the present study to examine if differences in the home environment 
exist based on infant birth order and sex. The HOME consists of 45 items (See Appendix E - Home Interview) and yields a total scale score and six subscale scores. The six subscales are as follows: I(Emotional and verbal responsivity of mother; II - Avoidance of Restriction and Punishment; III - Organization of the Physical and Temporal Environment; IV - Provision of Appropriate Play Materials; V - Maternal Involvement with the child; VI - Opportunities for Variety in Daily Stimulation (Bradley \& Caldwell, 1978).

A study conducted by Parks and Smeriglio (1986) suggests that a family's socioeconomic status may have an effect on the total HOME scores. This study reported that mothers of lower socioeconomic status had lower scores than mothers of middle and high socioeconomic status. They also reported that mothers of middle socioeconomic status may have lower total scores than mothers of high socioeconomic status. An early study conducted by Lichtenwalner and Maxwell (1969) suggests that socioeconomic status may influence a child's level of creativity. Lichtenwalner and Maxwell suggest that the lack of financial resources may limit the ability to provide a stimulating environment. In this same study it was suggested that lower class families exhibited more control over their children. In view of this finding, it would appear that socioeconomic level may be positively correlated with total HOME scores.

The present study not only examined the relationship of infant birth order and sex to mothers helping behavior it also examined the relationship of infant birth order and sex to aspects of the home environment using the HOME developed by Betty Caldwell (Bradley \& 
Caldwell1978). Discussed below are the specific predictions of this study.

\section{Predictions}

The intent of the present study is to explore if differences existed in mothers helping behavior in relation to the sex, and birth order of infants. Two predictions relating to these various interactions, and four related to the Home Interview are as follows:

1) It was predicted that mothers would help female infants to a greater extent when compared to mothers of male infants. Research findings by Olver et al 1989 and Block 1983 suggest that when compared to mothers of sons, mothers of daughters offer more help to their children during problem solving tasks.

2) It was predicted that mothers would express a significantly greater degree of helping behavior toward first-born infants as compared to second-born infants. Studies conducted by Rule 1991; Dunn, Stocker, and Plomin 1990, suggested that when compared to mothers of second-born infants, mothers of first-born infants tend to intervene more often during problem solving situations and offer help even when help is not needed.

3) It was predicted that mothers of first born infants would score higher on the Home Interview subscales I (Emotional and verbal responsivity of mother) and $V$ (Maternal involvement with child) as compared to second born infants. Research findings by Rothbart (1971) suggest that mothers of first born children exhibit greater pressure to achieve and are much quicker to intervene in the 
performance of their first born infants when compared to mothers of second born children.

4) It was predicted that mothers of second born infants would score significantly higher on the Home Interview sub-scale II (Avoidance of restriction and punishment) as compared to first born infants. The results of a study conducted by Rule (1991), suggested that when compared to mothers of first-born children, mothers of second born children tended to be less strict and controling in the lives of their child.

5) It was predicted that mothers of female infants will score higher on Home Interview scales I (Emotional and verbal responsivity of mother) and $V$ (Maternal involvement with child) when compared to male infants. Research conducted by Olver, et al (1989), supports this prediction based on the reported findings that mothers of females tended to be more intrusive, and more anxious to intervene in the lives of their daughters when compared to mothers of male infants.

6) It was predicted that mothers of male infants will score higher on Home interview sub-scale II (Avoidance of restriction and punishment) when compared to female infants. A study conducted by Olver, et al (1989) suggested that when compared to mothers of daughters mothers of sons appeared to foster more independence 


\section{METHOD}

\section{Subjects}

The sample for this study consisted of a total of sixty mother/ infant dyads. In order to control for differences based on social class, the sample was drawn from a middle class population. Families selected for this study were in the income range between $\$ 20,000$ to $\$ 100,000$. The sample consisted of the following subgroups:

There were a total of sixty children and their mothers randomly selected to participate in this study. All the subjects participating in the study were one year old infants ( $+/$ - one month) and their mothers. There were four subgroups within this sample. These subgroups were divided into fifteen male and fifteen female first-born infants, and also fifteen male, and fifteen female second born infants. These subjects were obtained in birth reports in local newspapers. Letters were sent to 145 parents describing the study and informing them to expect a phone call within the week to ask if they were interested in participating (See Appendix B). Approximately one week after the letters were sent, I began the phone calls. If they chose to participate, I would discuss the project in more detail and set an appointment. Of those that were called, the first sixty who chose to participate constituded the sample.

\section{Procedures}

One visit to the home was made by the researcher. The entire visit lasted approximately one hour. A standard format was used during the home visit in order to remain consistent. Before the 
Home Interview, the mother was told that the task portion of the visit would be videotaped for coding purposes only (See Appendix C Coding sheet) and would be kept confidential. Before the session began, the mother was asked to sign an informed consent form (See Appendix D).

First, the HOME Interview was administered to the mother (See Appendix E). This served as a warm up period in which the mother and child became more comfortable with the researcher. The HOME took approximately thirty minutes to administer, and was performed using a standardized interview protocol.

After the HOME interview, the mother was given instructions in regard to how to proceed with the tasks she was expected to present to her infant. The ordering of the tasks remained the same for every subject tested. The order in which the four tasks were administered was arranged from easiest to hardest so the child would not get frustrated and discouraged. The tasks were presented in the following standard order to each subject in the study: 1) Cubes in cup task 2) Pink puzzle board task 3) Blue puzzle board task 4) Stack cube task. The mother was given the same instructions twice, the first time in detail, and the second time briefly in order to make sure the mother fully understood what she was expected to do (See Appendix G). Immediately following these instructions, the mother was given the first problem-solving task. Instructions for all four tasks were similar (See Appendix $H$ ).

During the problem solving tasks the child sat on a child's chair seated in front of a child size table. These tasks were not timed, therefore the mother was instructed to let the researcher 
know when she felt her child could do no more. It was explained to the mother that some of the tasks being presented were difficult for some children because some of them are a bit above their age. The researcher told the mother that it was not important the child solve the problem, rather, the interest was in seeing how the child approached these difficult situations. Each of the tasks was then administered to the child by the mother.

The way the puzzle task was presented in the Rothbart (1971) study was similar to the present study. The puzzle was presented to the child by the mother. However, the puzzle task in the Rothbart study was timed for six minutes, whereas, in the present study the puzzle task was not timed. Both the Rothbart and the present study instructed the mother that she may help the child as much as she felt necessary. In the Rothbart study, the mother was told she could help the child as long as she did not solve it herself. In the present study, no limitations were placed on the mother as to how much or how little the mother was able to help the child.

\section{Instruments}

Demographic data were collected to control for potential differences among the subjects. These items were intended to control marital status, family income, job type, and level of education. Additional questions, such as, age, child care experience, and number of siblings the mother had were added to gain insight into the mother's background (See Appendix J). 
1. HOME Interview.

The Home interview is an instrument that allows researchers to learn more about the infant's home environment in terms of mother/child daily interactions, and general stimulation potential. There is also an observational section in which the experimenter observes mother/child interaction during the interview. The Home Interview has been empirically tested in regard to its validity, and reliability using the Kuder-Richardson, Person Product-Moment Coefficient correlation (6mo Vs.12 mo), and the Intra-Class Coefficient correlation analyses. Results of these tests found the validity of the six Sub-scales to be internally consistent, and stable over time. The internal consistency of Sub-scale I (Emotional and Verbal Responsivity of Mother) using the Kuder-Richardson was found to be .72 . Sub-scale I was found to have a correlation of .32 for consistency and stability using the Person Product-Moment analysis. The Intra-Class coefficient correlation testing for consistency and stability of Sub-scale I was found to be.31.

The internal consistency of Sub-scale II (Avoidance of Restriction and Punishment) using the Kuder-Richardson test for consistency and stability over time was found to be .67. The Person Product-Moment coefficient correlation analysis for consistency and stability found Sub-scale II to have a correlation of .29. The IntraClass coefficient correlation found Sub-scale II to have a correlation of .23 for consistency and stability.

The Kuder-Richardson test for consistency and stability of Sub-scale III (Organization of the Environment) was found to have a correlation of .89. The Person Product-Moment coefficient 
correlation found Sub-scale III to have a correlation of .45 for consistency and stability. The Intra-Class coefficient correlation of Sub-scale III testing for consistency and stability was found to be .43 .

Results of the Kuder-Richardson test for consistency and stability found Sub-scale IV (Appropriate Play Materials) was found to have a correlation of .77. The results of the Person ProductMoment test for consistency and stability found Sub-scale IV to have a correlation of .40 . The results of the intra-Class coefficient correlation for consistency and stability found Sub-scale IV to have a correlation of .30 .

Sub-scale V (Maternal Involvement with Child) was found to have a correlation of .69 using the Kuder-Richardson test for consistency and stability. The results of the Person ProductMoment coefficient correlation found Sub-scale $V$ to have a correlation of .47 for consistancy and stability. The results of the Intra-Class coefficient correlation analysis found Sub-scale $V$ to be consistent and stable with a correlation of .45 .

The internal consistency and stability correlation for Subscale VI using the Kuder-Richardson was found to be .44. The Pearson Product-Moment coefficient correlation found the stability and consistency of Sub-scale VI to be .62 , and the Intra-class coefficient correlation was found to be .57 .

The overall stability and consistency of the HOME Inventory Sub-scales was tested and referred to as total HOME score. The stability and consistency of the total HOME score using the KuderRichardson was found to be 89 . The results of the Pearson Product- 
Moment coefficient correlation analysis found the total HOME score to have a consistency and stability correlation of .62. The IntraClass coefficient correlation analysis found the consistency and stability of the total HOME score to be .57 .

One reason the overall consistency and stability correlations of the HOME Sub-scales and total HOME scores using the Pearson Product-Moment and Intra-Class coefficient correlation may be lower when compared with the correlations using the KuderRichardson analyses may be be in part due to sample size. The sample size used with the Kuder-Richardson test was 174, where as, the sample for both the Pearson Product-Moment and the Intra-Class analyses was 91 . The chances of having skewed results with a smaller sample size is greater than if the sample was larger Regardless of these differences, all three tests found the Home Interview to be a valid, and reliable test for gaining insight into the quality of a child's home environment.

2. Problem-Solving tasks.

All the problem-solving materials used were taken from a standard Bayley test box of toys. These individual items were not tested as separate from the Bayley test for reliability and validity. The four problem solving tasks used were developed for this study. There is no validity or reliability scores on these tasks as of yet. However, these four items were similar to those used in Lasko (1954). The toys (and other materials) used in this experiment consisted of the following: The first task was to have the child put 10 one-inch red cubes in a cup. The second task was a pink board puzzle from the Bayley. The puzzle was $8 \times 10$ (containing 1 
triangle, 1 circle, and 1 square (all pieces are 2.25"). The third task was a blue board puzzle from the Bayley. This puzzle was $7.75^{\mathrm{n}} \mathrm{x}$ 7.75" (containing 5 square pieces and 4 circle pieces) (all pieces are $\left.1.5^{\prime \prime}\right)$. The last task was a stacking task. The child was given ten one inch red cubes. He/she was to stack as many cubes as possible. The child was supplied with a little child table, and child chair on which he/she was to perform the tasks.

The event sampling technique was used to calculate the number of times the mother engaged in predefined behaviors. These predefined behaviors were positive statements, negative statements, verbal interventions, and behavioral interventions. The coding was performed from the video tapes. The range of the inter rater reliability scores for the behavioral interventions between the four tasks was between .80 to .91 with a mean of .86 . Inter rater reliability scores were also caculated for the four verbal interactions, they were as follows: Instruction .90, Negative statements 1.0, Positive statements 1.0, Unrelated statements .75 . The mean across all four verbal interactions was .87 .

\section{Measures}

The independent variables for both the HOME Interview and the problem-solving task portions of this study were sex of the child (male or female) and birth-order (first-born and second-born).

\section{HOME Interview}

The dependent variables on the Home Interview section of this study was defined as scores on Home Inventory Sub-scales I, II, and V (I - Emotional and verbal responsivity of mother, II - Avoidance 
of restriction and punishment, V - Maternal involvement with child). (See Appendix F - Home inventory code sheet).

2. Problem Solving Tasks

The dependent variables on the observational Problem-Solving section of this study were operationally defined as follows:

- NUMBER OF BEHAVIORAL INTERVENTIONS- Number of times mother behaviorally intervened (i.e., Mother touched the items herself, or moved the child's hand to help him/her, or non-verbal pointing).

- INSTRUCTIONS - Number of prompts (e.g., Strictly verbal instructions: Telling the child how to use the puzzle pieces/blocks/cubes, or pointing to where the object should go.)

- NEGATIVE STATEMENTS - The frequency mother used negative words to discourage child. (i.e., "No, don't do that".)

- PRAISE OR POSITIVE STATEMENTS - The frequency mother praised the child for desired behavior . (i.e., Clap, or words to the effect "Good Girl/Boy").

UNRELATED STATEMENTS - Verbal statements that are directed to the child but are not related to the task.

3. Demographical Variables

The mother was given a demographic questionaire designed specifically for this study. The intention of this questionaire was to get a fuller picture of their family's general background, such as, age, level of education, and socioeconomic status to name just a few. (See Appendix J) 


\section{RESULTS}

The general analyses used in this study were Anova and correlational analyses. The two independent variables in this study were sex and birth-order of the infant. The depenent variables were Mothers helping behavior across five areas: behavioral interventions, verbal instruction, negative statements, praise/positive statements, and unrelated statements. The overall sex and birth order effects were tested using Anova analyses. Although no significant findings were found for sex of the infant, there were some significant differences found regarding birth order using the same test for the total sample.

Birth-order differences were further analyzed to control for sex using an Anova analysis. Again the independent variables were birth order and sex of the infant, and the dependendent variables were the five areas of mothers helping behaviors.

An Anova analysis was used to test mothers' scores on the HOME interview. The independent variables were birth order and sex of the infant. The dependent variables were HOME subscales I, II, and V (I - Emotional and Some significant differences were found for birth order. The findings are discussed below in terms of the specific research objectives of the study. 
Table 1.

Means and Standard Deviations for Helping behavior and HOME scores. by infant sex and birth order

\begin{tabular}{|c|c|c|c|c|c|c|c|c|}
\hline $\begin{array}{l}\text { MOTHERS } \\
\text { HELPING } \\
\text { BEHAVIOR }\end{array}$ & \multicolumn{2}{|c|}{$\begin{array}{c}\text { Females } \\
N=30 \\
\text { Mean SD }\end{array}$} & \multicolumn{2}{|c|}{$\begin{array}{l}\text { Males } \\
N=30 \\
M S D\end{array}$} & \multicolumn{2}{|c|}{$\begin{array}{c}\text { First born } \\
N=30 \\
\text { Mean SD }\end{array}$} & \multicolumn{2}{|c|}{$\begin{array}{c}\text { Second born } \\
N=30 \\
\text { Mean SD }\end{array}$} \\
\hline $\begin{array}{l}\text { Behavioral } \\
\text { Intervent }\end{array}$ & 7.96 & 2.95 & 9.11 & 2.90 & 8.06 & 3.01 & 9.01 & 2.88 \\
\hline \multicolumn{9}{|c|}{ Total Group $(\mathrm{N}=60)$ Mean $=8.53 \quad \mathrm{SD}=2.96$} \\
\hline Instructions & 5.64 & 2.77 & 6.90 & 3.21 & 6.47 & 2.91 & 6.07 & 3.20 \\
\hline \multicolumn{9}{|c|}{ Total Group $(\mathrm{N}=60)$ Mean $=6.27 \quad \mathrm{SD}=3.04$} \\
\hline $\begin{array}{l}\text { Negative } \\
\text { Statements }\end{array}$ & .53 & .72 & .70 & .58 & .82 & .80 & .42 & .38 \\
\hline \multicolumn{9}{|c|}{ Total Group $(\mathrm{N}=60)$ Mean $=.62 \quad \mathrm{SD}=.65$} \\
\hline $\begin{array}{l}\text { Positive } \\
\text { Statements }\end{array}$ & 1.26 & .80 & 1.25 & .95 & 1.27 & .84 & 1.24 & .91 \\
\hline \multicolumn{9}{|c|}{ Total Group $(\mathrm{N}=60)$ Mean $=1.25 \mathrm{SD}=.87$} \\
\hline $\begin{array}{l}\text { Unrelated } \\
\text { Statements }\end{array}$ & 3.21 & 1.85 & 3.02 & 1.93 & 2.70 & 1.82 & 3.53 & 1.88 \\
\hline \multicolumn{9}{|c|}{ Total Group $(\mathrm{N}=60)$ Mean $=3.15 \quad \mathrm{SD}=1.88$} \\
\hline & & & & & & & & \\
\hline \multicolumn{9}{|l|}{ HOME } \\
\hline Sub-scale I & 9.13 & 1.07 & 9.67 & 1.18 & 9.30 & 1.34 & 9.50 & .94 \\
\hline \multicolumn{9}{|c|}{ Total Group $(\mathrm{N}=60)$ Mean $=9.40 \quad \mathrm{SD}=1.15$} \\
\hline Sub-scale II & 6.10 & .96 & 6.23 & .97 & 5.87 & 1.14 & 6.47 & .63 \\
\hline \multicolumn{9}{|c|}{ Total Group $(\mathrm{N}=60)$ Mean $=6.17 \quad \mathrm{SD}=.96$} \\
\hline Sub-scale V & 3.50 & 1.22 & 3.50 & 1.20 & 3.67 & .84 & 3.33 & 1.47 \\
\hline
\end{tabular}


Table 2.

Means and Standard Deviations for Demogaphic variables by infant sex and birth order

\begin{tabular}{|c|c|c|c|c|c|c|c|c|}
\hline \multirow{2}{*}{$\begin{array}{l}\text { Demograph- } \\
\text { ics } \\
\text { Mother's aat }\end{array}$} & \multicolumn{2}{|c|}{$\begin{array}{c}\text { Females } \\
N=30 \\
\text { Mean SD }\end{array}$} & \multicolumn{2}{|c|}{$\begin{array}{c}\text { Males } \\
N=30 \\
\text { Mean SD }\end{array}$} & \multicolumn{2}{|c|}{$\begin{array}{c}\text { First born } \\
N=30 \\
\text { Mean SD }\end{array}$} & \multicolumn{2}{|c|}{$\begin{array}{c}\text { Second born } \\
N=30 \\
\text { Mean SD }\end{array}$} \\
\hline & 30.33 & 4.76 & 29.30 & 4.79 & 28.07 & 4.23 & 31.57 & 5.68 \\
\hline \multicolumn{9}{|c|}{ Total Group $(\mathrm{N}=60)$ Mean $=29.82 \mathrm{SD}=4.76$} \\
\hline Father's age & 32.00 & 4.69 & 31.40 & 5.97 & 30.27 & 4.67 & 33.13 & $\overline{5.64}$ \\
\hline \multicolumn{9}{|c|}{ Total Group $(\mathrm{N}=60) \quad$ Mean $=31.70 \quad \mathrm{SD}=5.33$} \\
\hline $\begin{array}{l}\text { Mother's } \\
\text { educ. }\end{array}$ & 2.53 & .94 & 2.37 & .89 & 2.53 & .94 & 2.37 & .89 \\
\hline \multicolumn{9}{|c|}{ Total Group $(\mathrm{N}=60)$ Mean $=2.45 \quad \mathrm{SD}=.91$} \\
\hline $\begin{array}{l}\text { Father's } \\
\text { educ. }\end{array}$ & 2.67 & 1.12 & 2.50 & 1.07 & 2.70 & 1.06 & 2.47 & 1.14 \\
\hline \multicolumn{9}{|c|}{ Total Group $(\mathrm{N}=60)$ Mean $=2.58 \quad \mathrm{SD}=1.09$} \\
\hline $\begin{array}{l}\text { Marital } \\
\text { Status }\end{array}$ & 1.00 & 0.00 & 1.00 & 0.00 & 1.00 & 0.00 & 1.00 & 0.00 \\
\hline \multicolumn{9}{|c|}{ 60) Mean $=1.00 \quad S D=0.00$} \\
\hline $\begin{array}{l}\text { Mother's } \\
\text { Siblings }\end{array}$ & 2.00 & 1.23 & 2.03 & 1.07 & 1.73 & 1.01 & 2.30 & 1.21 \\
\hline \multicolumn{9}{|c|}{ Total Group $(\mathrm{N}=60)$ Mean $=2.02 \quad \mathrm{SD}=1.14$} \\
\hline $\begin{array}{l}\text { Mother's } \\
\text { experience } \\
\text { babysitting }\end{array}$ & .90 & .31 & .97 & .18 & 93 & .25 & .93 & .25 \\
\hline \multicolumn{9}{|c|}{ Total Group $(\mathrm{N}=60)$ Mean $=.93 \quad \mathrm{SD}=.25$} \\
\hline $\begin{array}{l}\text { Mother's } \\
\text { experience } \\
\text { in day care } \\
\text { settings }\end{array}$ & .37 & .49 & .27 & .45 & .33 & .48 & .30 & .47 \\
\hline \multicolumn{9}{|c|}{ otal Group $(\mathrm{N}=60)$ Mean $=.32 \mathrm{SD}$} \\
\hline Course & .50 & .51 & .67 & .48 & .63 & .49 & 53 & .51 \\
\hline \multicolumn{9}{|c|}{ Total Group $(\mathrm{N}=60)$ Mean $=.58 \mathrm{SD}=.50$} \\
\hline $\begin{array}{l}\text { Child Dev. } \\
\text { Course }\end{array}$ & .07 & .25 & .13 & .35 & .07 & .25 & .13 & .35 \\
\hline
\end{tabular}


Table 2 (Continued)

Means and Standard Deviations for Demographic variables by infant sex and birth order.

\begin{tabular}{|c|c|c|c|c|c|c|c|c|}
\hline $\begin{array}{l}\text { Mother's } \\
\text { work }\end{array}$ & .83 & .38 & .90 & .31 & .93 & .25 & .80 & .41 \\
\hline \multicolumn{9}{|c|}{ Total Group $(\mathrm{N}=60)$ Mean $=.87 \quad \mathrm{SD}=.34$} \\
\hline Work stat & 46.27 & 19.9 & 41.67 & $16.6 !$ & 41.70 & 19.14 & 46.23 & 17.66 \\
\hline \multicolumn{9}{|c|}{ Total Group $(\mathrm{N}=60)$ Mean $=43.97 \mathrm{SD}=18.40$} \\
\hline Income & 5.33 & 2.07 & 4.70 & 1.60 & 5.13 & 1.96 & 4.90 & 1.79 \\
\hline
\end{tabular}

\section{Specific Predictions}

The first prediction - that mothers would help female infants to a greater extent when compared to mothers of male infants concerned a subgroup analyses based on sex. No overall effect regarding sex of infant was found, using the anova analysis, $F(1,59)$ $=1.07, p>.05$. in terms of mothers' behavioral interventions, instructions, negative statements, positive statements, or unrelated statements. Since no overall significant sex differences were found, subgroup analyses based on sex of infant were not conducted.

The data provided partial support for the second prediction that mothers will express a significantly greater degree of helping behavior toward first-born infants as compared to second-born infants. There was an overall effect of birth order on mother's helping behavior. $F(1,59)=2.64, p<.033$. As can be seen in Table 3 , this overall effect exists because of the highly significant univariate influence of birth order on negative statements by the mother during the tasks $F(1,59)=6.18, p<.016$. 
Table 3

Anova analysis of the relationship of infant birth-order to mothers' helping behavior $(N=60)$.

\begin{tabular}{|l|c|c|c|}
\hline $\begin{array}{l}\text { Mothers } \\
\text { behavior }\end{array}$ & Mean square & E & P \\
\hline $\begin{array}{l}\text { Behavioral } \\
\text { Interventions }\end{array}$ & 13.58 & 1.57 & .22 \\
\hline Instructions & 2.32 & .25 & .62 \\
\hline $\begin{array}{l}\text { Negative } \\
\text { Statements }\end{array}$ & 2.43 & 6.18 & $.016^{\star}$ \\
\hline $\begin{array}{l}\text { Positive } \\
\text { Statements }\end{array}$ & .015 & .02 & .89 \\
\hline $\begin{array}{l}\text { Unrelated } \\
\text { Statements }\end{array}$ & 10.28 & 3.00 & .09 \\
\hline
\end{tabular}

Note. ${ }^{*} \mathrm{P}<.05$

An Anova analysis, referred to in Table 4, was performed to find out exactly where the significance was. This analysis was performed controlling for sex of the infant. The independent variables were birth-order and sex of the infant. The dependent variables were mother's helping behaviors, such as, behavioral interventions, verbal instruction, positive statements, negative statements, and unrelated statements. The results of this Anova analylsis suggested that for girls, birth order did not make a difference on any aspect of mothers' helping behavior. 
Table 4.

Anova analysis of birth order effects on mothers' helping behavior for girls $(\mathrm{N}=30)$

\begin{tabular}{|l|c|c|c|}
\hline $\begin{array}{l}\text { Mothers Helping } \\
\text { Behavior }\end{array}$ & Mean square & $\mathrm{E}$ & $\mathrm{P}$ \\
\hline $\begin{array}{l}\text { Behavioral } \\
\text { interventions }\end{array}$ & 3.63 & .41 & .53 \\
\hline Instructions & 9.20 & 1.21 & .28 \\
\hline $\begin{array}{l}\text { Negative } \\
\text { Statements }\end{array}$ & 1.15 & 2.34 & .14 \\
\hline $\begin{array}{l}\text { Positive } \\
\text { Statements }\end{array}$ & 1.51 & 2.46 & .13 \\
\hline $\begin{array}{l}\text { Unrelated } \\
\text { Statements }\end{array}$ & 4.51 & 1.33 & .26 \\
\hline
\end{tabular}

Note. No significant findings

The Manova analysis on Table 5 suggests that for boys, birth order made a difference in several aspects of mothers' helping behavior: Mothers used significantly more negative statements $F(1,29)=4.20$, $p=.05$, and unrelated statements $F(1,29)=19.33, p<.001)$. with their first born sons when compared with second born.

Table 5.

Anova analysis of the relationship of birth order effects for bovs to mothers' helping behavior $(N=30)$.

\begin{tabular}{|l|c|c|c|}
\hline $\begin{array}{l}\text { Mothers Helping } \\
\text { Behavior }\end{array}$ & Mean square & E & P \\
\hline $\begin{array}{l}\text { Behavioral } \\
\text { Interventions }\end{array}$ & 10.94 & 1.13 & .26 \\
\hline Instructions & .77 & .07 & .79 \\
\hline $\begin{array}{l}\text { Negative } \\
\text { Statements }\end{array}$ & 1.28 & $4.20^{\star}$ & .05 \\
\hline $\begin{array}{l}\text { Positive } \\
\text { Statements }\end{array}$ & 1.10 & 1.25 & .27 \\
\hline $\begin{array}{l}\text { Unrelated } \\
\text { Statements }\end{array}$ & 44.33 & 19.33 & $.0001^{\star \star}$ \\
\hline
\end{tabular}


The correlational analysis illustrated in Table 6 also provides partial support for the second prediction. The correlational data suggests that the direction of this effect is positive $(r=.31)$, which means that regardless of the infant's sex, mothers of first born children used more negative statements during the helping tasks.

Table 6.

Correlations between Structural Variables and Mother Helping Behavior for bovs and girls $(N=60)$.

\begin{tabular}{|l|c|c|}
\cline { 2 - 3 } \multicolumn{1}{c|}{} & Birth Order & Sex \\
\hline $\begin{array}{l}\text { Behaviroral } \\
\text { Interventions }\end{array}$ & - & - \\
\hline Instructions & - & - \\
\hline Negative Statements & .31 & - \\
\hline Positive Statements & - & - \\
\hline Unrelated Statements & - & - \\
\hline
\end{tabular}

Note. Numbers on Table were found to be significant at the .05 level or greater.

The correlational data did not provide support for the third prediction - that mothers of first-born infants will score higher on the Home Inventory sub-scales I (Emotional and verbal responsivity of mother) and $V$ (Maternal involvement with child) as compared to second born infants. There were no significant results found between first and second born infants in terms of mothers' scores on the Home Inventory sub-scale I (Emotional and verbal responsivity of mother) and sub-scale $V$ (Maternal involvement with child).

The correlational data provided support for prediction four Mothers of second born infants will score significantly higher on the Home interview sub-scale II (Avoidance of restriction and 
punishment) as compared to first born infants. Prediction four was supported by the findings of this study. Regardless of the infant's sex, mothers of second born children were found to score significantly higher on Home Inventory sub-scale II (Avoidance of restriction and punishment) $(r=.32)$. In other words, mothers of second born children avoided restricting and punishing their children significantly more than mothers of first born children.

The correlational data did not provide support for prediction five - Mothers of female infants would score higher on Home Inventory sub-scale I (Emotional and verbal responsivity of mother) and $V$ (Maternal involvement with child) when compared to male infants.

Also, correlational data did not support prediction six mothers of male infants would score higher on Home inventory subscale II (Avoidance of restriction and punishment) when compared to female infants. Sex of the infant did not yield significant results which corresponded to the Home inventory sub-scale II (Avoidance of restriction and punishment).

There were some findings in this study that were not specified in the predictions. One of the purposes of the present study was to examine relationships between mothers' helping behavior and the home environment. It was found that mothers who scored significantly higher on sub-scale II (Avoidance of restriction and punishment) also used less negative statements $(r=-.42)$. Mothers who gave more instructions were also found to use significantly more positive and negative statements. This would suggest that mothers who behaviorally and verbally intervened in the child's 
attempt to solve a given task, may also be more likely to structure the child's behavior toward solving the task. These mothers may do this by reinforcing the child's behavior through the use of positive and negative statements.

As seen on Table 7, mothers who scored higher on sub-scale $V$ (Maternal involvement with child), also gave significantly more instructions $(r=.27)$. This would suggest that the more the mother actively intervened in the child's activities, the more likely she was to give verbal instruction.

Table 7.

Correlational analysis between mothers helping behavior and the HOME

\begin{tabular}{|l|c|c|c|}
\cline { 2 - 4 } \multicolumn{1}{c|}{} & Sub-scale I & Sub-scale II & Sub-scale V \\
\hline $\begin{array}{l}\text { Behavioral } \\
\text { Interventions }\end{array}$ & - & - & - \\
\hline Instructions & - & - & .27 \\
\hline $\begin{array}{l}\text { Negative } \\
\text { Statements }\end{array}$ & - & .42 & - \\
\hline $\begin{array}{l}\text { Positive } \\
\text { Statements }\end{array}$ & - & - & - \\
\hline $\begin{array}{l}\text { Unrelated } \\
\text { Statements }\end{array}$ & - & - & - \\
\hline
\end{tabular}

Note. Numbers on Table were found to be significant at the .05 level or greater.

Along with studying mother/child interaction and the home environment, this study also examined the influence of various demographic factors. Although the demographic data did not significantly correlate with sex of the infant, there were 
significant correlations when demographic data were correlated with birth-order. For example, Table 8 shows mothers of second born children tended to be older than mothers who only had one child $(r=37)$. The same held true for fathers age $(r=.27)$. It was also found that mothers who had more than one child also had more siblings themselves when compared to mothers having only one child $(r=.25)$.

Table 8.

Correlational analysis between Demographic variables and BirthOrder.

\begin{tabular}{|l|c|c|}
\cline { 2 - 3 } \multicolumn{1}{c|}{} & First Born & Second born \\
\hline Mother's age & - & .37 \\
\hline Father's age & - & .27 \\
\hline Siblings & - & .25 \\
\hline
\end{tabular}

Note. Numbers on Table were found to be significant at the .05 level or greater.

Table 9 shows that older mothers tended to use more unrelated statements $(r=.33)$. Mothers who had previous experience in other child care settings tended to use significantly more negative statements $(r=.28)$ and mothers who had taken child development courses used significantly more positive statements with their children $(r=.30)$. In addition, mothers who worked before their child was born, displayed significantly more behavioral interventions than mothers who did not work previously $(r=.27)$. 
Table 9.

Correlational analysis between mothers' helping behavior and demographic variables.

\begin{tabular}{|l|l|l|l|l|}
\cline { 2 - 5 } \multicolumn{1}{l|}{} & $\begin{array}{l}\text { Mother's } \\
\text { Age }\end{array}$ & $\begin{array}{l}\text { Previous } \\
\text { experience } \\
\text { in day care } \\
\text { settings }\end{array}$ & $\begin{array}{l}\text { Child } \\
\text { Develop- } \\
\text { ment course }\end{array}$ & Work \\
\hline $\begin{array}{l}\text { Behavioral } \\
\text { Interven- } \\
\text { tions }\end{array}$ & - & - & - & .27 \\
\hline Instructions & - & - & - & - \\
\hline $\begin{array}{l}\text { Negative } \\
\text { Statements }\end{array}$ & .33 & .28 & - & - \\
\hline $\begin{array}{l}\text { Positive } \\
\text { Statements }\end{array}$ & - & - & .30 & - \\
\hline $\begin{array}{l}\text { Unrelated } \\
\text { Statements }\end{array}$ & - & - & - & - \\
\hline
\end{tabular}

Note. Numbers on Table were found to be significant at the .05 level or greater.

Table 10 shows that older mothers tended to score higher on Home inventory sub-scale II (Avoidance of Restriction and Punishment) than younger mothers ( $r$ - .25). Father's age correlated significantly with sub-scale $I(r=.25)$ and $V(r=.29)$. Also mothers who had experience baby-sitting scored significantly higher on subscale I (Emotional and verbal responsivity of the mother) when compared to mothers who did not have previous experience $(r=.27)$. 
Table 10.

Correlational analysis between HOME and Demographic variables

\begin{tabular}{|l|c|c|c|}
\cline { 2 - 4 } \multicolumn{1}{c|}{} & Mother's age & Father's age & $\begin{array}{l}\text { Experience } \\
\text { baby-sitting }\end{array}$ \\
\hline Sub-scale I & - & .25 & .27 \\
\hline Sub-scale II & .25 & - & - \\
\hline Sub-scale V & - & .29 & - \\
\hline
\end{tabular}

Note. Numbers on Table were found to be significant at the .05 level or greater.

Table 11 shows that mothers who used more behavioral interventions also used more instruction $(r=.45)$. Also, mothers who used more instructions also used more positive statements $(r=.54)$, and negative statements $(r=.26)$.

Table 11.

Correlational analysis beween aspects of mothers' helping behavior.

\begin{tabular}{|l|c|c|c|c|c|}
\cline { 2 - 6 } \multicolumn{1}{c|}{} & $\begin{array}{l}\text { Behavior } \\
\text { Intervent. }\end{array}$ & $\begin{array}{l}\text { Instruc- } \\
\text { tion }\end{array}$ & $\begin{array}{l}\text { Negative } \\
\text { State- } \\
\text { ment }\end{array}$ & $\begin{array}{l}\text { Positive } \\
\text { State- } \\
\text { ment }\end{array}$ & $\begin{array}{l}\text { Unrelated } \\
\text { State- } \\
\text { ment }\end{array}$ \\
\hline $\begin{array}{l}\text { Behavior } \\
\text { Intervent. }\end{array}$ & - & .45 & - & - & - \\
\hline $\begin{array}{l}\text { Instruc- } \\
\text { tion }\end{array}$ & - & - & - & - & - \\
\hline $\begin{array}{l}\text { Negative } \\
\text { State- } \\
\text { ment }\end{array}$ & - & - & - & - & - \\
\hline $\begin{array}{l}\text { Positive } \\
\text { State- } \\
\text { ment }\end{array}$ & - & .54 & - & - & - \\
\hline $\begin{array}{l}\text { Unrelated } \\
\text { State- } \\
\text { ment }\end{array}$ & - & .26 & - & - & - \\
\hline
\end{tabular}

Note. Numbers on Table were found to be sifnificant at the .05 level or greater. 


\section{DISCUSSION}

There has been extensive research in the field of human development involving mother/child interaction; sex of infant; birth-order, and the influences of the home environment on children. However many of these studies either examined only one of these areas independent from the others, or two of them as they may relate to one another. The intention of the present study was to examine the relationship of sex and birth-order of infants to mother/child interaction. The specific behaviors of the mother's that were under study were as follows: Behavioral interventions, instruction, positive statements, negative statements, and unrelated statements. The unique aspect of this study was that in conjunction with the above intentions it also examined the relationship of birth-order and sex of the infant to different aspects of the home environment. If significant differences in the home environment do exist further research could be done to examine the influences these differences have in relation to the cognitive and physical development of the child. A number of significant results were found in the present study.

Regardless of the infant's sex, birth-order was related significantly to some aspects of mother's helping behavior. For example, mothers used significantly more negative statements with first born children when compared with mothers of second born children.

Sex of the infant was found to have no significant relationship to mothers' helping behavior. This is an interesting finding in light of other research on this issue. Although the literature regarding 
the relationship of sex of an infant to mothers' helping behavior is mixed, many studies have found sex of an infant to be related to differences in mothers interactions with their children. For example, studies by Rothbart (1971) and Oliver, Aries, and Batos (1989), found that mothers interrupted and intervened more often in the lives of their daughters when compared to their sons. Studies by Minton, et al. (1971) and Fristad, and Karpowitz (1988), found the opposite to be true. They found that mothers interrupted and intervened more in the lives of their sons when compared to their daughters. Although the results of the studies just discussed are mixed, they all found relationships between infant sex and maternal interactions with her infant.

The present study found that sex of infants was not related to mother's helping behavior. This may have resulted because of sampling error or the sample being exceptional in one way or another. For example, geographic location of the sample used for the present study may have influenced the results of the study in that families may have tailored their behavior and interactions with their children in a way that is adaptable to their lifestyle. For example, families in urban areas may be exposed to more stimulation which may require them to act and react quicker than families living in rural areas. Although the tasks used in the present study were similar to the puzzle tasks used in Hilton (1967) and Rothbart (1971), they may not have been conducive to examining sex differences. As stated earlier, the tasks used were specifically designed for this study and have not been tested for validity or reliability. 
In the present study, it was found that mothers used significantly more negative and unrelated statements with first born boys when compared to second born boys. It was expected that mothers would use more negative statements with first born children but not necessarily just with boys. Mothers using more unrelated statements with first born boys was unexpected. No predictions were made in reference to unrelated statements. This was an interesting finding because it suggests that mothers may talk more to first born boys as opposed to second born boys. This finding may be associated with such things as being a first time parent and being concerned about the child doing the "right thing." These mothers may also be unsure about how to react to their child with a researcher/stranger in the house. Taking the Hawthorne Effect into account, mothers may be concerned with providing the researcher with what the mother thought the researcher wanted rather than interacting in the way she would normally with her infant had the researcher not been in the house.

The present study was also designed to examine relationships between the home environment and the sex and birth order of the child.

It was found that mothers did not differ in their emotional and verbal responsivity (Sub-scale I of the Home inventory) to first born and second born infants. Also, mothers were not found to be any more or less involved (Sub-scale $V$ of the Home inventory) with their first born infants than their second born infants. Regardless of birth order mothers were not found to differ in the amount of time they spent talking to their child, structuring play, or encouraging 
intellectual growth of the child. However, it was found that mothers of second born infants scored higher on sub-scale II of the home inventory interview (avoidance of restriction and punishment) when compared to mothers of first born infants.

Sex of the infant did not yield significant results in regard to the aspects of the home environment examined in this study. Mothers of males and females did not differ significantly in terms of their maternal involvement, emotional/verbal responsivity toward their child, or the use of punishment and restriction. The results found in this study concerning sex differences are not consistent with those conducted by Kagan, and Levine 1(971) and Fristad, and Karpowitz (1988) who found that sex of infants did make a difference in terms of maternal involvement. A potential explanation for the differing results may be due to differences across samples selected among these studies. These differences may relate to such things as geographic location, socioeconomic status, race, culture, and educational background.

In the present study, birth order effects for girls were not found to be related to any aspect of mother's helping behavior being examined. Although this particular finding did not support the prediction of the present study it is interesting because it is contradictory to past and current research. For example, a number of early studies conducted by Koch (1954) Lasko (1954); Rosen (1961) Stout (1960) Hilton (1967) and Rothbart (1971) all found that mothers reacted differently toward both boys and girls based on the child's birth order. A potential reason for differing results may be due to insufficient testing of the validity and reliability of the 
tasks used for this study. These results may also indicate changing attitudes regarding gender toward more egalitarian expectations.

For the sample as a whole, relationships were examined between scores on the HOME and mothers' helping behavior. Interestingly, mothers who scored higher on sub-scale $V$ of the home inventory (Maternal emotional and verbal involvement with child) also gave more instruction. This means that the more involved the mother was with the infant the more apt she may be to give instruction and vice versa. Based on the results of the present study it is interesting to note that mothers who scored higher on subscale II (Avoidance of restriction and punishment) also used less negative statements. This makes sense as mothers would use less negative statements toward the second-born children since they tend to avoid punishment and restriction of their child's activities. This would mean that mothers of second born infants are more apt to let their infant explore and learn about the environment on their own without interruption or restriction by the mother.

were significant findings in the present study with regard to some of the demographic factors. For example, it was found that mother's having more than one child also had significantly more siblings themselves when compared to mothers having only one child. Apparently family patterns are being followed.

An interesting finding of the study was that there appeared to be an experience factor on the part of the mother that may have influenced the way mothers interact with their infants. For example it was found that older mothers tended to use more unrelated statements when the child was performing the tasks. It is possible 
that older mothers may have had more life experience and therefore felt more comfortable and at ease under the circumstances of participating in a study. These mothers may have felt freer to respond to the child in ways that were unrelated to the tasks at hand. Mothers who had experience. working in child care settings were found to use significantly more negative statements than mothers who did not. This may suggest that these mothers may have been concerned with keeping order and structure as a priority.

It was also found in this study that mothers who had previous experience taking child development courses used significantly more positive statements than mothers who did not. One reason these mother may use more positive statements is because they may have learned the importance of using positive statements to encourage a child to learn. Another reason could be that they may be more realistic regarding expectations of child behavior and therefore more encouraging.

Mothers who had worked prior to the birth of their child were found to display significantly more behavioral interventions than mothers who did not. This was an interesting finding because it may be that mothers who had worked previously may be more concerned about doing the "right thing" to help their child learn. Mothers who had not worked previously, may be more relaxed in terms of letting the child learn on his or her own and at the child's own pace. Other potential explanations may be related to authority issues; control over environment; work ethic as more "driven", "energetic", or demanding of self and others. This would be an interesting study for future research. 
Older mothers were found to score higher on sub-scale II of the Home inventory (Avoidance of restriction and Punishment) when compared to younger mothers. This would suggest that older mothers may be more relaxed than younger mothers in terms of letting the child explore and learn about their environment on their own. Older mothers may be more confident that their child will learn at their own pace and may be less likely to push their child to learn. Younger mothers on the other hand may be preoccupied with trying to get their child to learn by helping and demonstrating the "right way" to do things. These younger mothers may also be overly concerned with how their child is learning in relation to other children their child's age.

The present study found that mothers who had previous babysitting experience scored significantly higher on the Home inventory sub-scale I (Emotional and verbal responsivity of the mother), than mothers who did not. This suggests that previous baby-sitting experience may provide mothers with evidence that responsivity is important for the needs of the child.

\section{Potential problems}

Potential problems with this study may relate to the sample selected to participated in the study. For example, there was little ethnic or cultural diversity in the sample. The entire sample was drawn from a relatively small geographic area. Ali the participants were white middle class families. These factors limit the generalization of the study in terms of ethnic/cultural, and socioeconomic status. 
for first born boys children as compared to second born. More specifically the present study found this difference in birth order as it related to boys. Birth order differences were not found for girls.

\section{Euture Studies}

The most relevant areas in the study appear to be birth order and age and experience of the mother including having siblings in their family of origin. We might say that experience is the key factor. Experience working, baby sitting, in taking child development courses, and with raising a previous child all have positive influences in mothers interactions with their child. Experience in other work settings including child care settings (other than babysitting), however contributed to more intrusive and negative interactions. Future research relating to mothers "experience" in the areas mentioned above needs to be conducted to further explore the ways that "mother's experience" influences interactions with her child during problem solving situations. 
References

Bardwick, J. M., \& Douvan, E. (1971). Ambivalence; The socialization of women. Women in Sexist Society New York: Basic Books, 262273.

Block, J. H. (1983). Differential premises arising from differential socialization of the sexes: Some conjectures: Child Development. 54, 1335-1354.

Bradley, R., \& Caldwell, B. (1978): Screening the environment. American Journal of orthopsychiatry 48. 114-129.

Dunn, J., Stocker, C., \& Plomin R. (1990). Non-shared experiences within the family: Correlates of behavioral problems in middle childhood: Development and Psychopathology 113-126.

Fristad, M. A., \& Karpowitz, D. H.; (1988). Norms for the children's report of parental behavior inventory-modified form: Psychological Reports, 62, 665-666.

Gunnar-Von, Gnechten, M. R. (1978). Changing a frightening toy into a pleasant toy by allowing the infant to control its actions. Developmental Psychology 14. 157-162.

Hilton, I. (1976). Differences in the behavior of mothers toward first- and later-born children: Journal of Personality and Social Psychology 7, 282-290.

Lasko, J. K. (1954). Parent behavior toward first and second children. Genetic Psychology Monographs. 49, 96-137.

Lichtenwalner, J. S., \& Maxwell, J. W. (1969). The relationship of birth order and socioeconomic status to the creativity of preschool children: Child Development, 40, 1241-1247.

Milton, C., Kagan, J. \& Levine J. A. (1971). Maternal control and obedience in the two-year-old: Child Development. 42, 19731894.

Olson, S. L., Bates, J. E., \& Bayles K. (1984). Mother-infant interaction and the development of individual differences in 
children's cognitive competence: Developmental Psychology 1. 166-179.

Olver, R. R., Aries, E., \& Botgos, J. (1989). Self-other differentiation and the mother-child relationship: The effects of sex and birth order: Journal of Genetic Psychology 50, 311-321.

Parks, P. L., \& Smeriglio V. L. (1986). Relationships among parenting knowledge quality of stimulation in the home and infant development: Family Relations: 35, 411-416.

Rothbart, M. K., (1971). Birth order and mother-child interaction in an achievement situation: Journal of Personality and Social Psychology 17,113-120.

Rule, W. R., (1991). Birth order and sex as related to memory of parental strictness-permissiveness: Psychological Reports. 68, 908-910.

Stout, A. M. (1960). Parent behavior toward children of differing ordinal position and sibling status: Unpublished Doctoral dissertation University of California. 


\section{APPENDIX A}

\section{Extensive Review of Literature}

Birth-order and sex differences have been increasing sources of interest in the behavioral sciences for several decades. One of the purposes of this study was to examine the relationship of birthorder and sex of the child to behavior of the mother toward the infant. Another purpose of this study was to examine the relationship of birth and sex of the child to the home environment to find out if differences exist.

\section{SEXDIFFERENCES}

A study by Bardwick and Douvan (1971) found that women have been characterized as having more difficulty than men in developing a separate sense of self, because to a large extent females define themselves in terms of their success within their interpersonal relationships. Women are often found to define their self-worth in terms of their involvement in interpersonal relationships. They tend to have a difficult time separating how they feel about situations, and how others feel about the situation (Aries \& Olver, 1985). This same study suggests that men, on the other hand, define their selfworth based on their own internal standards. This sex difference is thought to have its origins in infancy in the differential response of mothers to sons and daughters (Aries \& Oliver, 1985). Beginning at birth males and. females are raised with very different stereotypes of what normal masculine and feminine personality characteristics are thought to be. An early study by Bardwick and Douvan (1971), defined some of these stereotypes. They ask "What are big boys made of?", and "What are big girls made of?" Listed below are a few 
examples the Bardwick and Douvan (1971) study pointed out. Boys are made of the following: Independence, aggression, competitiveness, leadership, task orientation, outward orientation, assertiveness, and so forth. Girls on the other hand, are raised with practically the opposite expectations. According to the Bardwick and Douvan (1971) study, girls are made of the following:

Dependence, passivity fragility, low pain tolerance, nonaggression, non-competitiveness, inner orientation, interpersonal orientation, empathy. Bardwick and Douvan suggested that these sex differences may have their origin in infancy with regard the different ways parents interact with their children based on the child's sex.

Much of the research examining the relationship of sex of infants to mother/child interaction have had mixed results. The majority of the studies on mother/child interaction of male and female infants found there to be differences. However those studies which found differences to exist could not reach a consensus regarding if mothers interacted more with male infants or female infants. Some studies cited in this review found that the infants sex had no effect on mother/child interaction.

Although each of the studies described below have mixed results, the intent of each study was to examine the relationship of the sex of infants to mother/child interaction. The potential relationship of the sex of the infant to mothers' behavior toward her child is one of the questions being examined in the present study.

A study conducted by Smith and Daglish (1977) was designed to examine sex differences in parent and infant behavior in the home. The visit made to the home by the researcher consisted of observing 
mother interaction with the child during free play. The kind of maternal behavior being examined was as follows:

Discourage/punish \& help/explain. The results of this study found no significant main effects based on the infant's sex. However, it was found that there was a tendency for mothers to discourage/punish boys more than girls.

Rothbart and Rothbart (1976) designed a study to examine the relationship of birth order and sex of the child to maternal help giving. The mother was asked to supervise their child's performance on puzzle and memory tasks. The results of this study suggested that mother's behavior toward their infant did not differ significantly regardless of the child's birth-order or sex. However this study suggested that mother's were more likely to be more responsive to requests for help by their daughters than by their sons.

The study conducted by Gunnar, and Donahue (1980), was designed to examine sex differences in social responsiveness. The researcher used a one way mirror to observed mother/child interactions during play. The results of this study revealed no significant differences in maternal responsiveness to their male or female infants. However girls were found to be more responsive to their mothers vocalizations and attempted to evoke responses from their mother.

Research conducted by Olver, Aries, and Batgos, 1989, suggested that mothers tend to be more highly involved with and intrusive in the lives of their daughters as opposed to their sons. This study also suggested that mothers tend to foster independence in their sons when compared to mothers of daughters. This suggests 
that mothers appear to allow more exploratory behavior and restrict sons less than daughters.

On the other hand, similar research was conducted showing the opposite to be true; that mothers are more intrusive in the lives of their sons (Minton, et al 1971; Fristad, \& Karpowitz 1988). Minton, et al (1971), reported in their study that mothers were more apt to reprimand and/or remove their sons from a situation when compared to the behavior displayed by the mother in terms of how she reacts to her daughter. Many early observational studies cited in Block (1983) conducted by Gunnar-Von, Gnechten, (1978) and Rothbart, (1971), suggested that mothers of daughters provided more help in problem-solving situations than mothers of boys, even when their help is not required. The findings of these studies suggest that mothers of daughters will intervene and behaviorally demonstrate how the task is to be performed even if the infant does not try to evoke help from their mother. These same studies also suggest that mothers of boys will intervene less often giving their infants time to explore and solve problems on their own.

\section{BIRTHORDER DIFFERENCES}

Literature on birth-order suggests that the problems involved in developing a separate sense of self may be heightened for firstborns (Olver, Aries, \& Batgos 1989). The difficulty for first born children developing a separate sense of self may have its origin in infancy related to parental strictness verses permissiveness. Rule (1991), examined birth order and sex as it related to memory of parental strictness versus permissiveness. The sample was composed of 116 university students (45 men, 52 women, 19 not 
responding). The students were asked to fill out a questionaire regarding their memory of the strictness-permissiveness of each parent. The results from this study support many early studies by Rothbart 1971; Hilton 1967; Matas, Arerd, and Stroufe 1978. all of which found that parents were more controlling with their first born children when compared to later born. The study conducted by Rule (1991) suggested that firstborn children recalled greater parental control toward themselves than when compared to with their later born sibling(s). This study supports one prediction of the present study in that mother's would express significantly more helping behavior toward first born children when compared to second born children.

Previous research has documented a number of differences in parental behavior toward first and later-born children. There are many early studies cited in Hilton (1967) which support this idea. Koch (1954), for example, reported that parents pay more attention to first-born children. In his study, Koch found that mothers of first born children talk to and instruct their children more than mothers of second born children. In this same study, Koch found that mothers of first born boys gave their children more attention than mothers of first born girls and second born children. This attention was given in the form of verbal instruction and verbal stimulation. Stout (1960) and Lasko (1954), both found that parents are more directive with the first born child. Lasko's study also suggested that parents of second children "interfered" less often than parents of first born children. Both early research conducted by Rothbart (1971) and Matas, et. al. (1978), and more recent research by Rule (1991) and 
Dunn , Stocker and Plomin (1990) regarding birth order agree that first-born children (accentuated in first-born females) will receive more help from mother during problem solving tasks even when help is not needed (Rothbart 1971). Lasko (1954) used a variety of scales to measure "interference." The scales were as follows: "Quantity of suggestion," "Readiness of criticism," "Acceleration attempt," and "Readiness of explanation." These scales were similar to the scales used for the present study.

Recent research conducted by Dunn, et al (1990); and Rule (1991) looked at the relationship of maternal behavior to first and later born children to examine if differences exist. Dunn, et al (1990) conducted a study which examined shared and non-shared experience between siblings of differing birth order in terms of whether these experiences correlate with behavioral problems in middle childhood. The results of this study suggested that differences in maternal behavior toward her child may be a predictor of adjustment problems in later stages of development. The maternal behavior under study were based on two dimensions, Affection, and Control. The data for each of these dimensions were based on a video play-back of mother/child interaction participating in six play settings lasting for 30 minutes. The Affection and Control dimensions were coded using a five point scale. Affection was defined as the following: (1) negative or discouraging remarks, no positive remarks, no physical affection; (3) some praise, positive comments, some smiles, laughs; and (5) many positive comments, many smiles, positive physical contact. The Control dimension was defined as the following: (1) no intruding or directive remarks, does 
not handle game pieces or take on child's role; (3) some helpful comments, a few directive comments not in question form, or several suggestions including questions, suggestions for play; and (5) many directive comments, controls child physically, takes child's part in game, organizes child's play. The maternal behavior examined in Dunn et. al. (1990) are very similar to the maternal behavior examined in the present study (Refer to Appendix C - Code sheet). The results of Dunn. et. al (1990) suggest that there is greater maternal control expressed toward first born children when compared to later born. This finding supports a prediction of the present study- that mothers will express more helping behavior toward first-born children when compared to second-born children. Another interesting finding in the Dunn et. al. (1990) study, was that in families where mothers expressed more affection toward the first born child as compared with the later born, the older child was less likely to show internalizing problems then in families where mothers expressed less affection toward their first born and more toward their later born. This study also suggested that the mothers who were more controlling toward first born children than to their later born, found that these older children had higher scores on the internalizing and externalizing problems scales. These findings could have implications for the results of the present study. If mothers behavior is found to be significantly correlated with infant birth order, the quality of maternal behavior toward her child could effect the way the child internalizes/externalizes problems in later life. 
Mothers' of second born infants have been found to show less extreme reactions to the failure or success of their child's performance. For example, mothers of first born infants have been found to reject there child by withdrawing love when the child failed and/or be overjoyed when the child succeeds. Related research has shown that mothers of second born children are much more consistent and less extreme regardless of the success or failure of their child's performance and to demonstrate less restriction and punishment toward their infant (Hilton 1967).

Lasko (1954) and Hilton (1967), found that when compared to parents of first born children, parents of second born children were more permissive. Lasko used the following scales to test permissiveness: "Justification of policy," "Restrictiveness of regulations," "Democracy of policy," "Readiness of enforcement." These scales used by Lasko appear comparable to some of the scales used in the present study both in terms of the observational aspects of the problem solving tasks (Refer to Appendix I for definition of mothers helping behaviors), and items on the Home Inventory used to access aspects of the home environment. (Refer to Appendix E). The scales used to study mother/child interaction during the four problem solving tasks in the present study were similar to those described in (Lasko 1954) The scales used in the present study were as follows: Behavioral interventions; Instruction; Negative statements; Positive statements; and Unrelated statements. Some of the scales used in the present study also appear comparable to some of the scales used by Lasko (1954). For example, Lasko's "Quality of suggestion" and "Readiness of explanation" scales are 
similar to the "Instruction" scale in the present study in that each of these scales refer to verbal instruction by the mother. Lasko's "Acceleration attempt" scale is comparable to the "Behavioral intervention" scale in the present study in that these scales refer to the mothers' avoidance or attempt to assist the child by way of demonstration or manipulating the child's hand in an effort to show the child what is expected in order to successfully complete the task. The "Restrictiveness of regulation" scale in Lasko's (1954) study appears comparable to the "Negative statement" scale in the present study in that both scales measure the mother's attempt to keep the child's behavior goal directed by discouraging off-task behavior via negative statements.

Rosen (1961) described parents as talking and interacting more with first born children. Rosen found in his study that parents of first born and only children receive more achievement training than second born children. Rosen reports that only children tend to be anxiously trained, with some children being raised over strictly, and others being raised over indulged. The findings of the study conducted by Dunn, et. al. (1990) support the findings of Rosen by suggesting that there is greater maternal control expressed toward first born children when compared to later born. Lasko (1954) reports that much of the anxiety mothers of first born children have may be due to being a parent for the first time. Many parents in his study verbalized their anxieties, frustrations, and ignorance over being unsure of how to care for their first born child.

The study conducted by Sutton-Smith, Roberts, and Rosenberg 1964, referred to pressure placed on the first-born child to achieve 
and be responsible. They reported that first born children have a strong identification with their parents. These children were found to express a high degree of conformity, dependency, conscience, and affiliation in relation to their parents. These traits have been reported in this study to lead to academic success. Sampson (1962) also found that these pressures are extended to only children as well. Early studies by McArthur (1954), Rosen (1961), and more recent studies by Dunn et. al. (1990) and Rule (1991), support the findings of Sutton-Smith, Roberts, and Rosenberg (1964) that first born children have more pressure placed upon them by their parents to succeed.

Early studies by Rothbart (1971), and Hilton (1967) have found that mothers will often pressure first-born children toward successful completion of problem solving type tasks. In Hilton's (1967) study, mothers were given differential information about their child's success or failure in order to compare mothers interactions with first-born and second-born children on a puzzle task. In the study conducted by Hilton (1967), it was found that mothers of first born children used significantly more positive statements as a way of demonstrating love when their child would succeed on the task. Mothers of first born children were also found to withhold positive demonstration of love when the child would fail on a task. In the same study, it was noted that mothers of second born children were more consistent and less extreme in their demonstration of love in reference to the child's success or failure on a given task. In this same study, it was also reported that there was a greater amount of maternal interference with first-born, and 
only children on several variables. Mothers of first-born and only children rated as "more involved" were more likely to initiate work on the puzzle task, and gave more task-oriented suggestions, and direct help to first-born children. Rothbart's (1971) study found that mothers of first born children were rated as more "intrusive" than mothers of second born children. In this study it was noted that mothers of second born children were more likely to wait until the child started on the task before she helped in any way.

The studies discussed above are all are similar to the present study in that each study was designed to examine the relationship of infant birth order and sex to mother/child interaction during problem-solving or structured play situations.

\section{HOME}

The Home Environment for Measurement of the Environment (HOME) was designed by Betty Caldwell a child Psychologist. The HOME was designed to examine if differences existed in children's home environment. The HOME interview is divided into six sub-scales. Subscale 1 measures both emotional and verbal responsivity of mother and is coded in relation to eleven items on the HOME interview. Subscale 1 is highly subjective because it is based on the observer's perception of the mothers' responsiveness to her child rather than answers the mother has provided. Sub-scale 2 measures avoidance of restriction and punishment. This scale is also based on observations and judgements of the interviewer and is therefore subjective. There are eight items coded for the outcome of this scale. Sub-scale 3 measures the organization of physical and temporal environment. In other words, this scale measures the 
organization, consistency and safety of the child's home environment. There are a total of six items coded for the results of this sub-scale. Sub-scale 4 measures provision of appropriate play materials. The types of things this sub-scale refers to is the types of toys and activities that are available to the child in the home environment. There are a total of nine items scored for the results of this sub-scale. Sub-scale 5 measures maternal involvement with her child. This sub-scales surveys the mother's daily verbal and behavioral involvement with her child. There are a total of six items coded for the results of this sub-scale. Sub-scale six measures the opportunities for variety in daily stimulation. This sub-scale surveys the amount of variety of stimulation via toys and people on a daily, weekly, or monthly basis. This sub-scale consists of five items. There are obviously differences in the quantity of items within the six sub-scales, however, the Home Interview has been researched and been emperically tested using the KuderRichardson, and test-retest reliability and has been found to be a reliable and valid instrument (Bradley and Caldwell 1978).

Lasko's 1954, study designed scales similar to the sub-scales found in the HOME interview. The results of Lasko's study strengthened the idea that the home environment and mother's interaction with her child may influence the way the child learns about his/her environment. For example, Lasko's use of the "Readiness of reinforcement" scale appears comparable to the "Praise or Positive statement scale" in the HOME in that both scales measure the mothers effort to reinforce desired behavior via positive reinforcement. Results of a study conducted by Olson, 
Bates and Bayles (1984), suggested that infants learning abilities are enhanced when the caretaker rewards the child's desired behavior with immediate positive feedback. The Home Inventory sub-scale II (Avoidance of restriction and punishment), is sensitive to picking up on items relating to restriction and punishment. This Home inventory sub-scale 11 used in the present study is similar to what Lasko (1954) referred to as the "Restrictiveness of regulation scale" in his study. Home inventory sub-scale I (Emotional and verbal responsivity of mother), and sub-scale $V$ (Maternal involvement with child), may be sensitive to some of the areas that some scales in Lasko's study are sensitive to in regard to emotional, verbal, and behavioral involvement on the part of the mother.

Recent research by Sroufe cited in Honig (1991), and similar research by Isabella, Belsky, and Von Eye (1989), found differences in mothers' helping behavior using problem-solving situations similar to those in the HOME inventory. Research by Matas, et. al. (1978), Isabella and Belsky (1991), found that some mothers observed in problem-solving situations refrain from excessive helping behavior. Rather, these mothers allow their-infant to draw on their own personal and environmental resources. These mothers were observed to do the following in controlled problem-solving situations: provide help only when necessary; focused the child on the task as needed; shared in the enjoyment of the problem-solving situation; helping the child have a sense of achievement in solving the problem-solving task him/herself. Based on the mother's perception of the infants signals, some mothers displayed strikingly different behaviors, such as, being minimally involved, overly 
intrusive, and intervening inappropriately (Isabella \& Belsky 1991; Isabella, Belsky \& Eye, 1989).

A study conducted by Parks and Smeriglio (1986), suggest that socioeconomic status may have an effect on total HOME scores. This study found that low socioeconomic status mothers had lower scores than middle socioeconomic status mothers. This study also found mothers of middle socioeconomic status to have lower scores than mothers of high socioeconomic status. Another study by Lichtenwalner and Maxwell (1969), suggested that social class influences children's level of creativity. Some of the reasons given for these results relate to lack of financial resources needed in order to provide a stimulating environment. In this same study it was suggested that lower class families were found to exert more control over their children thereby repressing their child's creativity. Creative thinking and behavior are essential in the problem solving tasks used in the present study. There were combined annual income cut-off points designed for this study. These cut-offs were used in an effort to control for differences that may exist as a result of socioeconomic status.

The intent of this study was not only to examine the relationship of birth order and sex of infants to mother's helping behavior, but also to examine if differences exist within the home environment based on the child's birth-order and sex. It is obvious there are mixed findings in the literature in regard to the relationship of infant birth order and sex to mother/child interaction. This clearly indicates that more research needs to be done in these areas. 


\section{APPENDIX B \\ Letter to Parents}

Dear parents, my name is Cynthia O'Connell. I am currently working on my Master's Thesis project under the supervision of Dr. David Caruso for which you are asked to participate. Your name has been selected from the New London birth reports. I am a graduate student at The University of Rhode Island. The research under study involves exploring the relationship birth order and sex of infants have on mother/infant interaction during problem solving situations. For your convenience, the research project you are selected to participate in will involve one visit to your home lasting approximately one hour. I, Cynthia O'Connell, will be the person making this home visit. The visit will be broken down into two parts. The first part will involve a videotaped session involving you, the mother, and your infant during three problem solving tasks. These tasks will involve putting cubes in a cup, two puzzle tasks, and a stacking task. The second part of the home visit will involve interviewing the mother, about aspects of the home environment.

I will be calling you shortly to discuss the study in greater detail, and to answer any questions you may have concerning the study. I look forward to talking with you.

Thank you,

Cynthia A. O'Connell 


\section{APPENDIXC \\ CODING SHEET}

Subject Number

Mother's Name

Sex
Date

Child's Name

Birth Order

\section{BEHAVIORAL INTERVENTIONS}

\begin{tabular}{|l|l|}
\hline CUP TASK & \\
\hline PINK PUZZLE & \\
\hline BLUE PUZZLE & \\
\hline STACKING TASK & \\
\hline
\end{tabular}

VERBAL

\begin{tabular}{|l|l|l|l|l|}
\cline { 2 - 5 } \multicolumn{1}{c|}{} & CUP TASK & PINK PUZZLE & BLUE PUZZIEE & $\begin{array}{l}\text { STACKING } \\
\text { TASK }\end{array}$ \\
\hline $\begin{array}{l}\text { INSTRUC- } \\
\text { TION }\end{array}$ & & & & \\
\hline $\begin{array}{l}\text { POSITIVE } \\
\text { STATEMENT }\end{array}$ & & & & \\
\hline $\begin{array}{l}\text { NEGATIVE } \\
\text { STATEMENT }\end{array}$ & & & & \\
\hline $\begin{array}{l}\text { UNRELATED } \\
\text { STATEMENT }\end{array}$ & & & & \\
\hline
\end{tabular}


Appendix. D

The University of Rhode Island

Department of Human Development, Counseling, and Family Studies

Infant Research Project

Cynthia A. O'Connell

\section{CONSENT FORM FOR RESEARCH}

\section{Introduction}

I have been asked to take part in a Masters Thesis research project being conducted by Cynthia O'Connell. Cynthia will explain the project to me in detail. I should feel free to ask questions. If I should have more questions later, Cynthia (203) 536-1923 will discuss them with me.

\section{Description of the project}

I have been asked to take part in a study which is designed to examine the relationship of sex and birth order of the infant on mother/infant interaction during problem solving situations. The study will be conducted during one assessment period/ It will involve observing my infant and myself and interviewing me. The general purpose of this research is to learn more about differences in mother's reactions toward their infants based on the birth-order and sex of the infant.

\section{What will be done}

The research will be conducted during one visit at my home lasting approximately one hour. During the visit my infant and myself will be videotaped during attempts to solve four problem-solving tasks. Problem solving tasks used for this study involve putting cubes in a cup, two puzzle tasks, and a stacking task. Lastly, I will be interviewed about aspects of our home environment.

\section{Risks and discomforts}

This research has been designed to present no risks or discomforts to myself or my infant. If my infant gets tired or fussy, Cynthia will stop the procedures. Also, I may stop the procedures at any time. As part of researching families in the home environment, I am required by law to report any form of child neglect or abuse. 


\section{Appendix D \\ (Continued) \\ Consent Form for Research}

\section{Benefits of the study}

Although there will be no direct benefit to me or my infant for taking part in this study, the researcher may learn more about the effects birth-order and sex of infants have on mother/infant interactions during problem solving situations, and about the home life infants are exposed to which could help future parents. Confidentiality

Myself and my infant's part in the study is strictly confidential. None of the information resulting from this study will identify us by name. All records and videotapes will be maintained by the principal investigator except when they are being examined by research assistants for coding. Videotapes will be stored in a locked cabinet in the principal investigator's home. At no time will these records or videotapes be available to unauthorized persons or to persons not directly associated with this research project. If I should wish to have all recordings of me and my infant erased, this will be done at my request. These video tapes will be used only for the present research and will be destroyed at the completion of the study.

\section{In case of injury}

If this study causes me or my infant any injury, I should write or call The University of Rhode Island's Director of Research, 70 Lower College Road, University of Rhode Island, Kingston, RI 02881, telephone: (401) 792-2635.

\section{Decision to quit at any time}

The decision whether or not to take part in this study is up to me. I do not have to participate. If I decide to take part in the study, I may quit at any time. Whatever I decide will in no way penalize me. If I wish to quit I simply inform Cynthia O'Connell, (203) 536-1923, of my decision. 


\section{Appenxix D \\ (Continued) \\ Consent Form for Research}

\section{Rights and complaints}

If I am not satisfied with the way this study is performed, I may discuss my complaints with Cynthia's Major Thesis advisor Dr. David Caruso. (401) 792-5960. anonymously, if I choose.

I have read the Consent Form. My questions have been answered. My signature on this form means that I understand the information and I agree to have myself and my infant participate in the study.

Signature of Participant

Signature of Researcher

Typed/Printed Name

Typed/Printed Name

Date

Date 


\section{APPENDIXE \\ HOME INTERVIEW}

The Warm-UP

1. INTERVIEWER PRAISE CHILD - Mother's response should be positive and show pleasure

Item 11: Key- mother agrees, adds more facts to encouragepraise, beams, etc.

Yes No

2. WHAT WE'LL BE DOING TODAY IS AN INTERVIEW DEVELOPED BY BETTY CALDWELL, A CHILD PSYCHOLOGIST, TO HELP RESEARCHERS LEARN MORE ABOUT BABIES HOME LIVES WE USE A STANDARD FORMAT FOR THE INTERVIEW SO THAT WE DON'T LEAVE ANYTHING OUT AND TO MAKE IT THE SAME FOR ALL FAMILIES. I WILL BE MAKING NOTES AND CHECKING THINGS AS I GO ALONG SO THAT I DON'T HAVE TO REMEMBER IT ALL LATER.

3. YOU WILL REMEMBER THAT WE ARE INTERESTED IN KNOWING THE KINDS OF THINGS YOU BABY DOES WHEN HE/SHE IS AT HOME. A GOOD WAY FOR US TO GET AN OVERVIEW OF WHAT HIS/HER DAYS ARE LIKE IS FOR YOU TO THINK OF ONE PARTICULAR DAY - LIKE YESTERDAY - AND TELL ME HOW THE DAY WENT AS BEST AS YOU CAN REMEMBER IT. START WITH THE THINGS THAT HAPPENED FIRST WHEN HE/SHE WOKE UP.

PROMPTS:

A) WAS HE/SHE THE FIRST ONE TO WAKE UP?

Daily Home Routine

4. ONE OF THE HARDEST THINGS ABOUT HAVING YOUNG CHILDREN AROUND THE HOUSE IS THAT THEY ARE ALWAYS DEMANDING ATTENTION AND YOU HAVE A LOT.OF OTHER THINGS TO DO BESIDES PAY ATTENTION TO THEM. WHAT DOES YOU DO YOUR HOUSEHOLD CHORES - LIKE COOKING, CLEANING, LAUNDRY? 
PROMPTS:

APPENDIXE

(Continued)

HOME Interview

A: WHEN YOU DO HOUSEWORK, DO YOU CONCENTRATE ENTIRELY ON IT, OR DO YOU SOMETIMES MAKE CONVERSATION WITH AS YOU DOYOUR WORK?

ITEM 36: Key - mother talks and includes child in what she is doing, "well, mommy is going to wash dishes now."

Yes No

5. HOW DOES GET STARTED PLAYING WITH HIS/HER TOYS? DO YOU LET HIM/HER SELECT THINGS TO PLAY WITH OR DO YOU SOMETIMES MAKE SUGGESTIONS ABOUT CERTAIN TOYS HE .SHE SHOULD USE?

ITEM 39: Key - mother occasionally suggests something for child to do -- i.e., gives child something to play with when he is fretting.Mother can verbally suggest that the child play with something in order to receive credit Yes No

6. DOES YOUR CHILD ENJOY PLAYING WITH YOU OR DOES HE/SHE LIKE TO PLAY WITH HIS/HER TOYS BY HIMSELF/HERSELF MOST OF THE TIME?

PROMPTS:

A) WHAT TYPES OF ACTIVITIES THAT YOU DO WITH YOUR CHILD DOES HE/SHE SEEM TO ENJOY MOST?

B) ARE THERE ANY PARTICULAR GAMES THAT YOU LIKE TO PLAY WITH HIM/HER?

C) SOME PARENTS LIKE TO USE TOYS TO TRY TO TEACH KIDS CERTAIN THINGS BUT OTHERS THINK TOYS SHOULD JUST BE FOR PLAY. WHAT DO YOU THINK: DO YOU TRY TO TEACH WITH TOYS?

ITEM \# 37: key - mother sees herself as teacher. encourages development.

Yes

No 


\section{APPENDIXE \\ (Continued) \\ HOME Interview}

7. BABIES OF THIS AGE USUALLY LOVE TO PLAY IN THINGS THAT GET THEM ALL MESSY AND DIRTY - MUD, WATER, THEIR FOOD, AND SO ON. DOES YOU CHILD EVER WANT TO DO THIS KIND OF THING? HOW DO YOU FEEL ABOUT IT?

ITEM 7: Key - sand, mud, water, finger paint, etc.

Yes No

8. HOW DO YOU MANAGE MEAL TIMES AT YOU HOUSE? DO YOU FEED YOUR BABY AT THE TABLE WITH THE REST OF THE FAMILY, OR DO YOU FEED HIM SEPARATELY?

ITEM 43: Key - child must be right at the table with others and eatwith mother AND father every day. If no father figure it is scored no automatically.

Yes No

9. DOES HIS/HER FATHER GIVE YOU SOME HELP WITH $?$ PROMPT:

A. DOES HE DO THIS KIND OF THING REGULARLY AND FOR AT LEAST TEN MINUTES OR SO EACH DAY?

ITEM 41: Key - daily contact with "father figure."

\section{Outside Trips}

10. A CHILD AS YOUNG AS TIES A MOTHER DOWN MUCH OF THE TIME. DO YOU EVER MANAGE TO GET AWAY BY YOURSELF? OR DO YOU AND YOUR HUSBAND EVER GET TO GO OUT WITHOUT PROMMPTS: ?

A. (if yes). WHO TAKES CARE OF WHEN YOU ARE AWAY?

B. CAN YOU USUALLY COUNT ON HELP, OR DO YOU HAVE TO GET A DIFFERENT PERSON EACH TIME?

ITEM 20: Key - consistent sitter - predictable and stable social environment - no ore than three substitute caretakers Count father if mentioned.

Yes No 


\section{APPENDIXE}

(Continued)

HOME Interview

11. GIVE ME SOME EXAMPLES OF PLACES YOU GO AND TAKE with you?

PROMPTS:

A) (IF NOT MENTIONED) GROCERY STORE ?

ITEM 21: Key - any size store.

$$
\text { Yes No }
$$

B) DOCTOR'S OFFICE OR CLINIC:

ITEM 23: Key - once every few months during first year.

$$
\text { Yes No }
$$

C) ON AVERAGE, HOW MANY TIMES IN A WEEK DO YOU GET A CHANCE TO TAKE _ ON AN OUTING? EVEN IF IT'S ONLY TO THE YARD.

ITEM 22: Key - relative's or friend's home, zoo, museum, even out to yard counts - at least 4 per week).

Yes No

12. HOW OFTEN DO RELATIVES VISIT WITH YOU FAMILY?

ITEM 44: Key - score yes if approximately once per or more.

Define relative loosely.

Yes

No

Toys Available to the Child

13. I AM INTERESTED IN KNOWING SOMETHING ABOUT THE KINDS OF TOYS AND PLAY THINGS YOUR CHILD LIKES TO PLAY WITH. WHICH OF HIS/HER TOYS DOES HE/SHE LIKE THE BEST?

PROBES FOR SPECIFIC TOYS:

A. DOES HEISHE HAVE MUSCLE ACTIVITY TOYS LIKE BALLS, OR A DOOR SWING, ROCKING HORSE, CRIB GYM, JUMP-SEAT?

ITEM 26: Key - child must have access to the toy

$$
\text { Yes }
$$
No

B. DOES HE/SHE HAVE ANY TOYS THAT YOU PUSH OR PULL - LIKE A TOY LAWN MOWER, VACUUM OR CARPET SWEEPER, CORN-POPPERS, MUSIC BOXES ON A STICK, XYLOPHONE THAT IS PULLED BY A STRING, ETC.

ITEM 27: Key -- need not own -- must be available to the child to play with. 


\section{APPENDIXE}

(Continued)

HOME Interview

C. DOES HE/SHE HAVE ANY TOYS HE/SHE CAN RIDE ONSUCH AS A WALKER, KIDDIE-CAR, TRICYCLE, AND SO FORTH?

ITEM 28: Key - must be available to child Yes No

D. DOES HE/SHE HAVE A TEDDY BEAR, STUFFED ANIMAL, OR DOLL? ITEM 30: Key - toys to role play with even a cowboy suit or policeman'S hat -- make believe.

Yes No

E. DOES HE/SHE HAVE ANY TOYS FOR LEARNING ABOUT THE WORLD SUCH AS A PRETEND TABLE AND CHAIRS, CASH REGISTER, TOY KITCHEN, TOY PHONE?

ITEM 31: Key - a learning toy is the key to this item Yes No

F. DOES HESSHE HAVE ANY TOYS THAT HEJSHE CAN TAKE APART AND PUT BACK TOGETHER -- LIKE PUZZLES, SNAP-TOGETHER BEADS, ETC.?

ITEM 32: Key - provides eye-hand coordination toys -- items to in and out of receptable, fit together toys Yes No

G. DOES HE/SHE HAVE ANY BLOCKS OR TOYS THAT ONE CAN STACK OR BUILD WITH, -- LIKE TINKER TOYS?

ITEM 33: Key - the key feature here is combinations Yes No

14. HOW DO YOU DECIDE WHAT TO BUY WHEN YOU PURCHASE A NEW TOY FOR ?

ITEM 40: Key - mother can estimate child's ability and find materials that challenge the child.

Yes No 


\section{APPENDIXE \\ (Continued) \\ HOME Interview}

15. HOW DOES ACT WHEN HE/SHE GETS A NEW TOY? DO YOU USUALLY DEMONSTRATE HOW TO PLAY WITH IT OR IS THIS NOT USUALY NECESSARY?

ITEM 38: Key - mother encourages child by participating and demonstrating new toy that is a bit beyond the child's current abilities

$$
\text { Yes }
$$

No

16. DOES HE/SHE HAVE ANY BOOKS?

ITEM 45: Key three or more - can share with siblings but must belong primarily to index child Yes No

17. DOES HE/SHE LIKE TO BE READ TO OR SHOWN PICTURES IN A BOOK OR MAGAZINE?

PROMPT

A. (IF YES): ABOUT HOW OFTEN DO YOU FIND TIME TO READ TO OR LOOK AT A PICTURE BOOK TOGETHER?

ITEM 42: Key - three times weekly to score yes Yes No

18. DOES HE/SHE HAVE ANY MUSICAL TOYS, TALKING RECORDS OR MUSICAL INSTRUMENTS?

ITEM 34. Key - both a toy for literature and a toy for music must be available to receive credit, musical toy must be something the child can operate by himself-herself; radio is acceptable if child can turn it on and select a station; a rattle with a musical jingle is acceptable for infant; consider age of child when scoring this item

Yes No

19. DO YOU HAVE A SPECIAL PLACE THAT YOU KEEP HIS/HER TOYS? ITEM 24: Key - may be shared with other siblings but child must remove or return toys by himself, can be cardboard box, closet drawer, a plastic basket or paper bag

Yes No 


\section{APPENDIXE}

(Continued)

HOME Interview

20. (IF NOT VISIBLE): DO YOU HAVE A FAMILY PET?

ITEM 19: Key - an animal that the family takes care of and the child can play with or look at -- not temporary critter like a jar of lightning bugs.

Yes No

\section{Discipline}

21. WE ARE INTERESTED IN WHAT PARENTS DO TO KEEP THEIR CHILDREN FROM MISBEHAVING. HOW OFTEN DO YOU SPANK ?

\section{PROMPT:}

A. WHAT OTHER THINGS HAVE YOU FOUND TO BE EFFECTIVE IN DEALING WITH MISBEHAVIOR?

ITEM 15: Key - no more than one instance of physical punishment in the past week in order to score yes Yes No

22. WHAT DO YOU CONSIDER TO BE THE MOST DIFFICULT PART ABOUT BEING A PARENT OF A CHILD THIS AGE?

ITEM 13: Key - does she express overt annoyance of hostility toward child, does she complain that the child is hard to care for, is wearing her out, does she call him/her bad without joking

Yes

No 


\section{APPENDIXE}

Continued

HOME Inteview

ITEM 1: Mother vocalizes to child

Yes

No

ITEM 2: Mother responds to child's

Yes

No vocalizations

ITEM 3: Mother tells child name of object Yes

No

ITEM 5: Mother initiates verbal interaction Yes No with observer

ITEM 6: Mother gives more than brief

Yes

No answers

ITEM 8: Mother praises child twice

Yes

No

ITEM 9: Mother's voice conveys positive Yes

No feelings to child.

ITEM 4: Mothers speech clear

Yes

No

ITEM 10: Mother kisses child

Yes

No

ITEM 29: Mother provides toys or activities Yes

No for child.

ITEM 35: Mother keeps child within sight Yes

No

ITEM 25: Environment safe

Yes

No

ITEM 12: Mother does not shout

Yes

No

ITEM 14: Mother does not spank

Yes

No

ITEM 16: Mother does not scold or derogate Yes No

ITEM 17: Mother does not

Yes No No No restrict child 


\section{APPENDIX F \\ (Code Sheet - Birth to Three)}

Child's Name

Child's birth date

Relationship of person interviewed

to child
Date of Interview Interviewer

Place of interview

Family Composition

(Indicate persons living in household, including sex and age of children).

Persons present in home at time of interview

Comments

\begin{tabular}{|l|l|l|}
\hline \multicolumn{1}{|c|}{ Subscale } & Raw Score & $\begin{array}{c}\text { Percentile } \\
\text { Band }\end{array}$ \\
\hline $\begin{array}{l}\text { I Emotional and Verbal Responsivity of } \\
\text { Mother. }\end{array}$ & & \\
\hline $\begin{array}{l}\text { II Avoidance of Restriction and } \\
\text { Punishment }\end{array}$ & & \\
\hline $\begin{array}{l}\text { III.Organization of the Physical and } \\
\text { Temporal Environment. }\end{array}$ & \\
\hline $\begin{array}{l}\text { IV Provision of Appropriate Play } \\
\text { Materials }\end{array}$ & & \\
\hline $\begin{array}{l}\text { V. Maternal Involvement with the child } \\
\text { VI.Opportunities for Varriety in Daily } \\
\text { Stimulation. }\end{array}$ & & \\
\hline \begin{tabular}{l} 
Total \\
\hline
\end{tabular} & & \\
\hline
\end{tabular}




\section{APPENDIX F}

(Continued)

(Code Sheet - Birth to Three)

\begin{tabular}{|c|c|c|}
\hline $\begin{array}{l}\text { I.EMOTIONAL AND VERBAL RESPONSIVITY } \\
\text { OF MOTHER }\end{array}$ & YES & NO \\
\hline $\begin{array}{l}\text { 1. Mother spontaneously vocalizes to child at } \\
\text { least twice during visit (excluding scolding) }\end{array}$ & & \\
\hline $\begin{array}{l}\text { 2. Mother responds to child's vocalizations } \\
\text { with a verbal response. }\end{array}$ & & \\
\hline $\begin{array}{l}\text { 3. Mother tells child the name of some object } \\
\text { during visit or says name of person or object } \\
\text { in a "teaching" style. }\end{array}$ & & \\
\hline $\begin{array}{l}\text { 4. Mother's speech is distinct, clear, and } \\
\text { audible.. }\end{array}$ & & \\
\hline $\begin{array}{l}\text { 5. Mother initiates verbal interchanges with } \\
\text { observer--asks questions, makes } \\
\text { spontaneous comments. }\end{array}$ & & \\
\hline $\begin{array}{l}\text { 6. Mother expresses ideas freely and easily and } \\
\text { uses statements of appropriate length for } \\
\text { conversation (e.g., gives more than brief } \\
\text { answers. }\end{array}$ & & \\
\hline $\begin{array}{l}\text { "7.Mother permits child occasionally to engage } \\
\text { in "messy" types of play. }\end{array}$ & & \\
\hline $\begin{array}{l}\text { 8. Mother spontaneously praises child's } \\
\text { qualities or behavior twice during visit. }\end{array}$ & & \\
\hline $\begin{array}{l}\text { 9. When speaking of or to child, mother's voice } \\
\text { conveys positive feeling. }\end{array}$ & & \\
\hline
\end{tabular}




\section{APPENDIX F}

(Continued)

(Code Sheet - Birth to Three)

10.Mother caresses or kisses child at least once during visit.

11. Mother shows some positive emotional responses to praise of child offered by visitor.

\section{SUBSCORE}

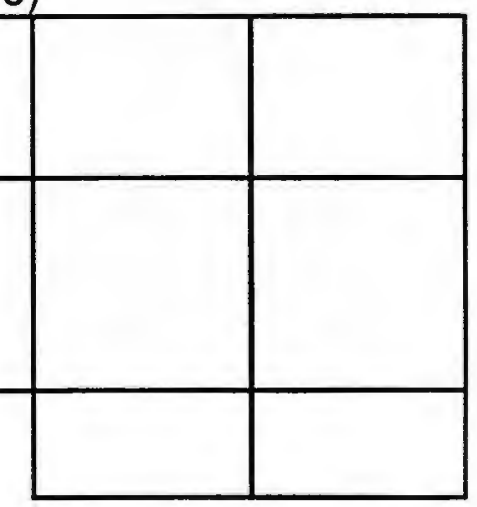

\begin{tabular}{|c|c|c|}
\hline $\begin{array}{l}\text { II. AVOIDANCE OF RESTRICTION AND } \\
\text { PUNISHMENT. }\end{array}$ & YES & NO \\
\hline 12. Mother does not shout at child during visit & & \\
\hline $\begin{array}{l}\text { 13. Mother doesn't express overt annoyance } \\
\text { with or hostility toward child. }\end{array}$ & & \\
\hline $\begin{array}{l}14 \text { Mother neither slaps not spanks child } \\
\text { during visit. }\end{array}$ & & \\
\hline $\begin{array}{l}\text { *15. Mother reports that no more than one } \\
\text { instance of physical punishment occurred } \\
\text { during the past week. }\end{array}$ & & \\
\hline $\begin{array}{l}\text { 16. Mother does not scold or derogate child } \\
\text { during visit. }\end{array}$ & & \\
\hline $\begin{array}{l}\text { 17. Mother does not interfere with child's } \\
\text { actions or restrict child's movements more } \\
\text { than three times during visit }\end{array}$ & & \\
\hline 18. At least ten books are present and visible & & \\
\hline *19. Family has a pet. & & \\
\hline SUBSCORE & & \\
\hline
\end{tabular}




\section{APPENDIX F}

(Continued)

(Code Sheet - Birth to Three)

(" Items from Categories I and II may require direct questions.)

\begin{tabular}{|l|l|l|}
\hline $\begin{array}{l}\text { III. ORGANIZATION OF PHYSICAL AND } \\
\text { TEMPORAL ENVIRONMENT. }\end{array}$ & YES \\
\hline $\begin{array}{l}\text { 20. When mother is away, care is provided by } \\
\text { one of three regular substitutes. }\end{array}$ & & \\
\hline $\begin{array}{l}\text { 21. Someone takes child into grocery store at } \\
\text { least once a week. }\end{array}$ & & \\
\hline $\begin{array}{l}\text { 22. Child gets out of house at least four times } \\
\text { a week. }\end{array}$ & & \\
or clinic. & & \\
\hline 23. Child is taken regularly to doctor's office & & \\
his toys and "treasures." & & \\
\hline $\begin{array}{l}\text { Child's play environment appears safe and } \\
\text { free of hazards. }\end{array}$ & & \\
\hline \multicolumn{2}{c}{ SuBSCORE } & \\
\hline
\end{tabular}

\begin{tabular}{|l|l|l|}
\hline $\begin{array}{l}\text { IV. PROVISION OF APPROPRIATE PLAY } \\
\text { MATERIALS. }\end{array}$ & YES & NO \\
\hline $\begin{array}{l}\text { 26. Child has some muscle activity toys or } \\
\text { equipment. }\end{array}$ & & \\
\hline 27. Child has push or pull toy & & \\
\hline
\end{tabular}




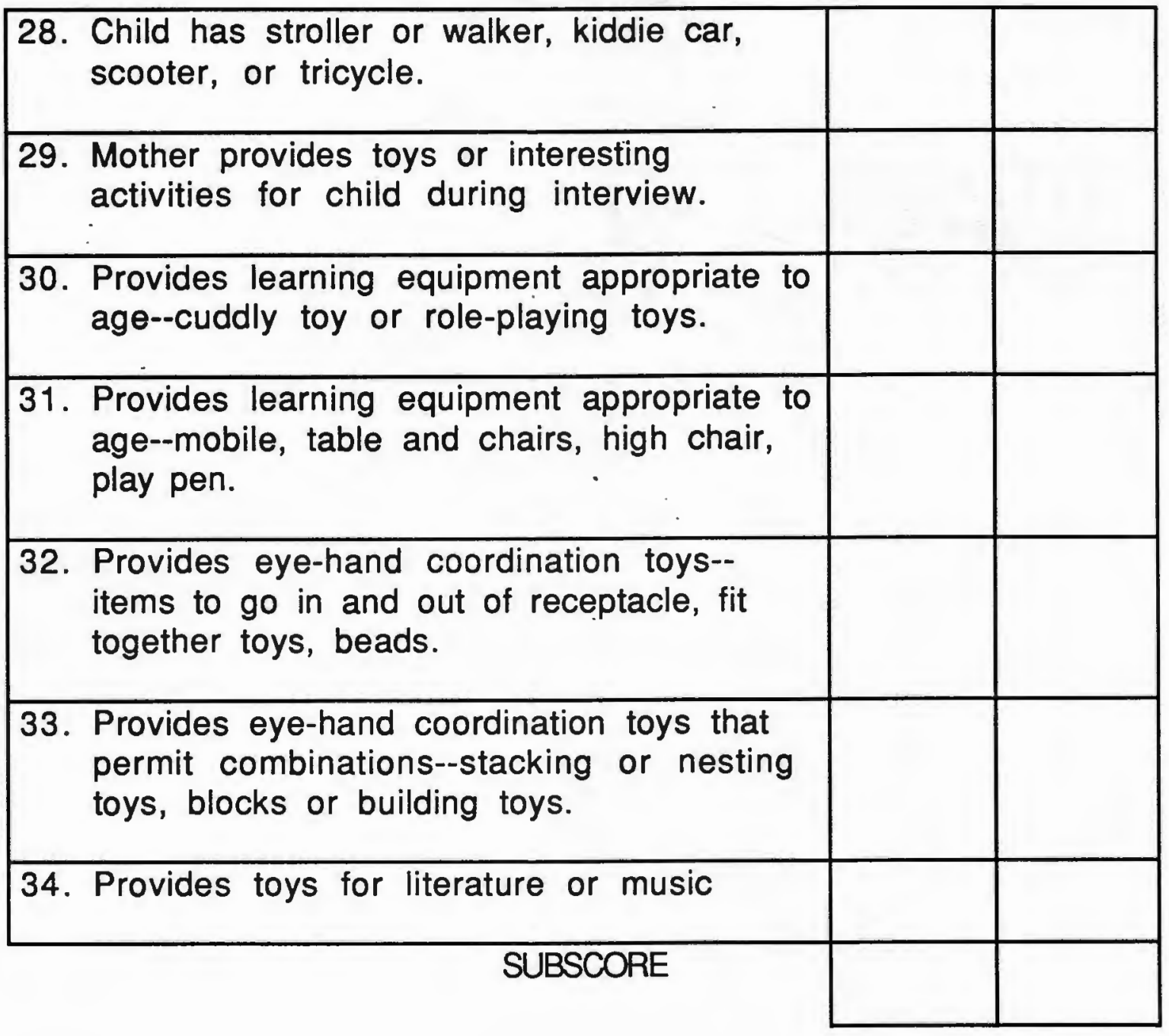

\begin{tabular}{|l|l|l|}
\hline V. MATERNAL INVOLVEMENT WITH CHILD & YES & NO \\
\hline $\begin{array}{l}\text { 35. Mother tends to keep child within visual } \\
\text { range and to look at him often. }\end{array}$ & & \\
\hline $\begin{array}{l}\text { 36. Mother "talks" to child while doing her } \\
\text { work. }\end{array}$ & & \\
\hline $\begin{array}{l}\text { 37. Mother consciously encourages } \\
\text { developmental advances. }\end{array}$ & & \\
\hline $\begin{array}{l}\text { 38. } \\
\text { Mother invests "maturing" toys with value }\end{array}$ & & \\
\hline
\end{tabular}




\section{APPENDIX F}

(Continued)

(Code Sheet - Bith to Three)

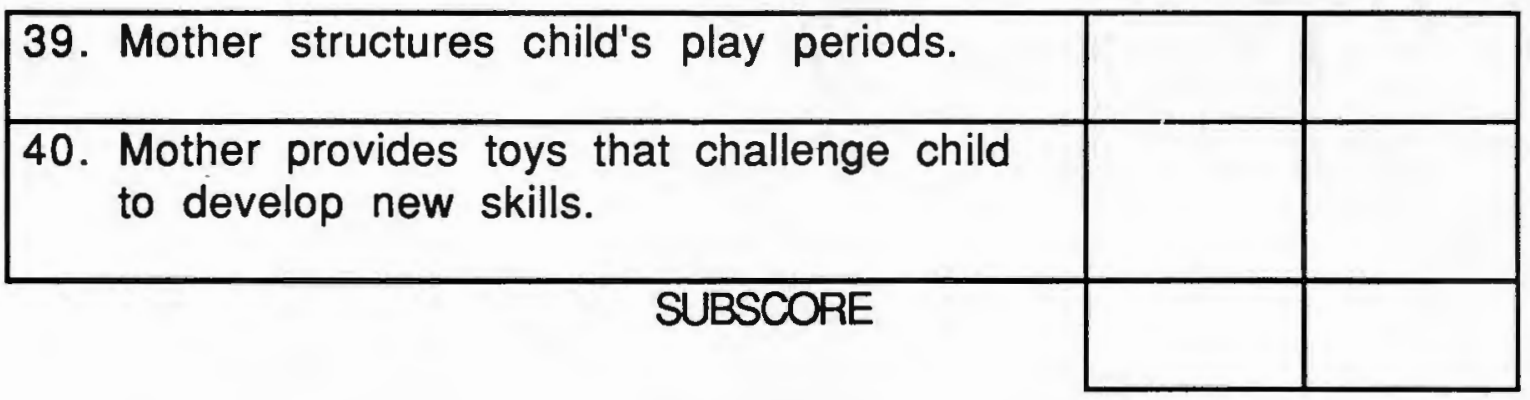

\begin{tabular}{|l|l|l|}
\hline $\begin{array}{l}\text { VI. OPPORTUNITIES FOR VARIETY IN DAILY } \\
\text { STIMULATION. }\end{array}$ & YES & ND \\
\hline $\begin{array}{l}\text { 41. Father provides some caretaking every day. } \\
\text { daily. } \\
\text { 42. Mother read stories at least three times }\end{array}$ & & \\
\hline $\begin{array}{l}\text { 43. Child eats at least one meal per day with } \\
\text { mother \& father. }\end{array}$ & & \\
\hline $\begin{array}{l}\text { 44. Family visits or receives visits from } \\
\text { relatives. }\end{array}$ & & \\
\hline 45. Child has three or more books of his own. & & \\
\hline
\end{tabular}




\section{APPENDIX G \\ (Instructions to mother)}

For this study, I am interested in exploring how birth order and sex of infants influence how learn about their world through exploration, and how they go about solving problems on their own. However, if you feel (child's name) is getting frustrated or needs help solving a task you may help in any way you see fit (detailed instruction).

Remember, I am interested in exploring how children go about solving problems on their own, but if you feel (child's name) needs help you may do so (brief instruction). 


\section{APPENDIX H \\ (Instructions of the tasks to the mother)}

Since the mothers in this study, are to act as teachers to their child, they are given a standard explanation of how each of these problem solving tasks works, and what she is to have her child do. The standard explanations the experimenter gives the mother for each of the tasks are as follows:

CUBES IN CUP TASK - What I would like you to do now is to try to get (child's name) to put these five cubes in the cup. This task is not timed, so let me know when you feel (child's name) has finished.

PUZZLE 1 pink board - (There is only one stipulation the mother must follow when initially presenting this puzzle to the child. The circle must be facing closest to the child.) What I would like you to do is explain to (child's name), in your own way, how to go about solving the puzzle. This task will not be timed, so let me know when you feel (child's name) is finished. It is not important that (child's name) is successful at completing the task, I am interested in how (child's name) approaches the situation

PUZZLE 2 blue board - I would now like you to do the same for this puzzle. Remember these tasks are not timed so let me know when you feel (child's name) has finished.

STACKING CUBES TASK - What I would like you to do is to try to get (child's name) to stack three cubes on top of one another. Some children have trouble doing this task because it is a little above their age. Again, let me know when you feel (child's name) has finished. If (child's name) successfully completes the task once, that is all he/she would have to do in order to receive full credit. Remember, (child's name) is not required to complete the task, just let me know when you feel (child's name) has finished. 


\section{Appendix 1 \\ Definitions of mothers helping behavior}

BEHAVIORAL INTERVENTIONS -

a) Any time mother touches materials, or infant in order to direct infant toward desired behavior.

b) Mother seats child back in the chair to re-orient child's attention.

c) Mother picks blocks up from floor to put them on the table (New interventions starts when a different task material is touched, or when touching the same task material is separated by at least 2 seconds).

d) Mother taps block or puzzle piece on table to re-orient child's attention to task.

e) Mother models desired behavior (i.e. Demonstrating putting cubes into the cup, or putting puzzle pieces in the puzzle board, or stacking blocks.

f)) Touching two materials simultaneously counts as one behavioral intervention.

INSTRUCTIONS - Verbal instructions: Put the cubes in the cup; are you going to put them in the cup again?; mother counts out loud.

a) Instructions usually occur before or during task.

b) Instructions can co-occur with behavioral interventions, negative statements, or praise.

c) Single word references to an item are coded separately.

Sentences need to be separated by at least two seconds to be coded separately.

d) Counting separate items are counted separately.

NEGATIVE STATEMENTS - (Verbal statements) No, don't do that; don't put that in your mouth; no, you have to sit down.

Appendix I Cont...

POSITIVE STATEMENTS - (Verbal statements) Praise; clap; good boy/girl; you are so smart; mother kisses child.

a) Both negative and positive statements usually occur after the task.

UNRELATED STATEMENTS - (Verbal statements) Any verbal statements not related to the tasks.

a) Verbal statements only include speaking to the baby. 


\section{APPENDIX $J$ \\ MOTHER'S BACKGROUND DATA QUESTIONNAIRE}

This information is strictly confidential and is used only to describe the study participants as a group. Information regarding individual families will not be reported.

1. Mother's Age

2. Father's Age

3. Mother's Education

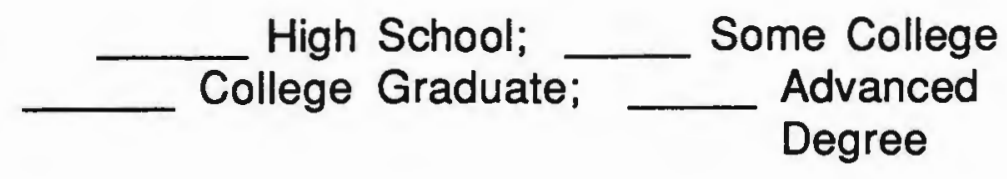

4. Fathers Education

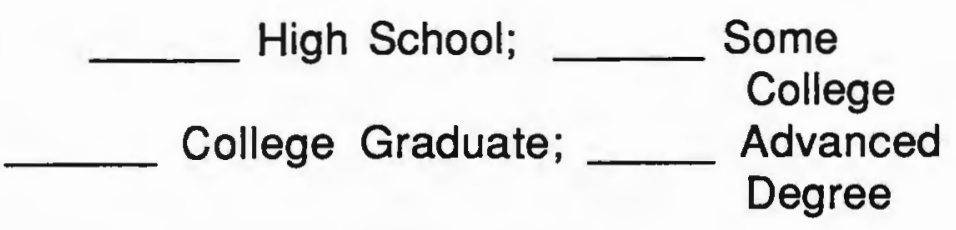

5. Marital status of biological parents of this child Married; _ Divorced; __ Separated; Remarried

6. Mother's number of siblings

7. Mother's experience babysitting Yes No.

8. Mother's experience working in other child care settings If Yes list

9. Did you ever take a course related to Child Development__Yes High School; College; How many No

10. Do you possess extensive education in Child Development Yes No. 


\section{APPENDIX $J$ \\ (Continued) \\ MOTHER'S BACKGROUND DATA QUESTIONAIRE}

11. Did you work before this child was born __ Yes No

12. What is your job(s)/profession(s)

13. Family income. Please check the income that best describes your total family income for the previous year.

Less than 10,000

20,000 to 30,000

40,000 to 50,000

60,000 to 70,000

80,000 to 90,000

Over 100,000
10,000 to 20,000

30,000 to 40,000

50,000 to 60,000

70,000 to 80,000

90,000 to 100,000 


\section{Bibliography}

Aries, E. J., Olver, R. R. (1985). Sex differences in the development of a separate sense of self during infancy. Directions for future research: Psychology of Women Quarterly, 9 , 515-532.

Bardwick, J. M., \& Douvan, E. (1971). Ambivalence: The socialization of women Women in Sexist Society New York: Basic Books, 262273.

Block, J. H. (1983). Differential premises arising from differential socialization of the sexes: Some conjectures. Child Development, 54,1335-1354.

Bradley, R., \& Caldwell, B. (1978). Screening the environment. American Journal of Orthopsychiatry. 48, 114-129.

Fristad, M. A., \& Karpowitz, D. H. (1988). Norms for the children's report of parental behavior inventory-modified form.

Psychological Reports, 62, 665-666.

Gunnar, M. R., \& Donahue, M. (1980). Sex differences in social responsiveness between six months and twelve months. Child Development, 51, 262-265.

Gunnar-Von \& Gnechten., M. R. (1978). Changing a frightening toy into a pleasant to by allowing the infant to control its actions. Developmental Psychology, 14, 157-162.

Hilton, I. (1976). Differences in the behavior of mothers toward first-and later-born children. Journal of Personality and Social Psychology, $\underline{7}, 282-290$.

Honig, A. S., (1991). Parent-child couples are the key: A review of Sameroff and Emde's relationship disturbances in early childhood. Merrill-Palmer Quarterly, 37, 519-522.

Isabella, R. A., \& Belsky, J. (1991). Interactional synchrony and the origins of infant-mother attachment: A replication study. Child Development, 61, 373-384. 
Isabella, R. A., Belsky, J., \& Eye, Alexander von. (1989). Origins of Infant-mother attachment: An examination of interactional synchrony during the infant's first year. Developmental Psychology, 25. 12-21.

EKoch, H. L. (1954). The relation of "primary nental avilities" in fiveand six-year olds to sex of child and characteristics of his sibling. Child Development, 25, 209-223.

Lasko, J. K. (1954). Parent behavior toward first an second children. Genetic Psychology Monographs, 49, 96-137.

Lichtenwalner, J. S., Maxwell, J. W. (1969). The relationship of birth order and socioeconomic status to the creativity of preschool chilren. Child Development, 40, 1241-1247.

Matas, L., Arerd, Richard A., \& Sroufe, A. L. (1978). Continuity of adaption in the second year: The relationship between quality of attachment and later competence. Child Devilopment, 49, 547556.

McArthur, C. (1956). Personalities of first and second children. Psychiartry, 19, 47-54.

Milton, C., Kagan, J. and Livine. J. A. (1971). Maternal control and obedience in the two-year-old: Child Development. 42, 18731894.

Olson, S. L., Bates, J. E., \& Bayles, K. (1984). Mother-infant and the development of individual differences in children's cognitive competence. Developmental Psychology, 1, 166-179.

Olver, R. R., Aries, E., \& Batgos, J. (1989). Self-other differentiation and the mother-child relationship: The effects of sex and birth order. Journal of Genetic Psychology 50, 311-321.

Parks, P. L., \& Smeriglio V. L. (1986). Relationships among parenting knowledge, quality of stimulation in the home and infant development. Family Relations, 35, 411 - 416.

Rosen, B. C. (1961). Family structure and achievement motivation. American Sociological Review, 26, 574-585. 
Rothbart, M. K. (1971). Birth order and mother-child interaction in an achievement situation. Journal of Personality and Social Psychology, 17, 113-120.

Rothbart, M. K., \& Rothbart, M. (1976). Birth-order, sex of child and maternal help giving. Sex Roles, 2, 39-46.

Smith, P. K., and Daglish, L. (1977). Sex differeences in parent and infant behavior in the home. Child Development. 48. 1250-1254.

Sampson, E. E. (1962). Birth order, need achievement, and conformity. Journal of Abnormal and Social Psychology, 64, 155159.

Stout, A. M. (1960). Parent behavior toward children of differing ordinal position and sibling status: Unpublished Doctoral dissertation. University of California.

Sutton-Smith, B., Roberts, J. M., \& Rosenberk B. G. (1964). Sibling associations and role involvement. Merrill-Palmer Quarterly, 10 , 25-38.

Warren, J. (1966). Birth order and social behavior. Psychological Bulletin, $\quad 65,38-49$.

Wertsch, J. V., McNamee, G. D., McLane, J. B., Budwig, N. A. (1980). The adult-child dyad as a problem-solving system. Child Development, 51, 1215-1221. 